\title{
How much is particulate matter near the ground influenced by upper-level processes within and above the PBL? A summertime case study in Milan (Italy) evidences the distinctive role of nitrate
}

\author{
G. Curci ${ }^{1}$, L. Ferrero ${ }^{2}$, P. Tuccella ${ }^{1}$, F. Barnaba ${ }^{3}$, F. Angelini ${ }^{4}$, E. Bolzacchini ${ }^{2}$, C. Carbone , $^{5}$ \\ H. A. C. Denier van der Gon ${ }^{6}$, M. C. Facchini ${ }^{5}$, G. P. Gobbi ${ }^{3}$, J. P. P. Kuenen ${ }^{6}$, T. C. Landi ${ }^{5}$, C. Perrino ${ }^{7}$, \\ M. G. Perrone ${ }^{2}$, G. Sangiorgi ${ }^{2}$, and P. Stocchi ${ }^{5}$ \\ ${ }^{1}$ CETEMPS Centre of Excellence, Department of Physical and Chemical Sciences, University of L'Aquila, L'Aquila, Italy \\ ${ }^{2}$ POLARIS Research Centre, Department of Earth and Environmental Sciences, University of Milano Bicocca, Milano, Italy \\ ${ }^{3}$ Institute for Atmospheric and Climate Sciences (ISAC), National Research Council (CNR), Rome, Italy \\ ${ }^{4}$ Italian National Agency for New Technologies, Energy and Sustainable Economic Development (ENEA), Rome, Italy \\ ${ }^{5}$ Institute for Atmospheric and Climate Sciences (ISAC), National Research Council (CNR), Bologna, Italy \\ ${ }^{6} \mathrm{TNO}$ Climate, Air and Sustainability, Princetonlaan 6, 3584 CB Utrecht, the Netherlands \\ ${ }^{7}$ Institute of Atmospheric Pollution Research (IIA), National Research Council (CNR), Rome, Italy
}

Correspondence to: G. Curci (gabriele.curci@aquila.infn.it)

Received: 20 August 2014 - Published in Atmos. Chem. Phys. Discuss.: 22 October 2014

Revised: 21 December 2014 - Accepted: 9 February 2015 - Published: 9 March 2015

\begin{abstract}
Chemical and dynamical processes lead to the formation of aerosol layers in the upper planetary boundary layer (PBL) and above it. Through vertical mixing and entrainment into the PBL these layers may contribute to the ground-level particulate matter (PM); however, to date a quantitative assessment of such a contribution has not been carried out. This study investigates this aspect by combining chemical and physical aerosol measurements with WRF/Chem (Weather Research and Forecasting with Chemistry) model simulations. The observations were collected in the Milan urban area (northern Italy) during the summer of 2007. The period coincided with the passage of a meteorological perturbation that cleansed the lower atmosphere, followed by a high-pressure period favouring pollutant accumulation. Lidar observations revealed the formation of elevated aerosol layers and evidence of their entrainment into the PBL. We analysed the budget of ground-level $\mathrm{PM}_{2.5}$ (particulate matter with an aerodynamic diameter less than $2.5 \mu \mathrm{m}$ ) with the help of the online meteorology-chemistry WRF/Chem model, focusing in particular on the contribution of upper-level processes. Our findings show that an important player in determining the upper-PBL aerosol layer is particulate nitrate, which may reach higher values in the upper PBL
\end{abstract}

(up to $30 \%$ of the aerosol mass) than in the lower PBL. The nitrate formation process is predicted to be largely driven by the relative-humidity vertical profile, which may trigger efficient aqueous nitrate formation when exceeding the ammonium nitrate deliquescence point. Secondary $\mathrm{PM}_{2.5}$ produced in the upper half of the PBL may contribute up to $7-8 \mu \mathrm{g} \mathrm{m}{ }^{-3}$ (or $25 \%$ ) to ground-level concentrations on an hourly basis. The residual aerosol layer above the PBL is also found to potentially play a large role, which may occasionally contribute up to $10-12 \mu \mathrm{g} \mathrm{m}^{-3}$ (or $40 \%$ ) to hourly ground-level $\mathrm{PM}_{2.5}$ concentrations during the morning hours. Although the results presented here refer to one relatively short period in one location, this study highlights the importance of considering the interplay between chemical and dynamical processes occurring within and above the PBL when interpreting groundlevel aerosol observations.

\section{Introduction}

The understanding of processes governing atmospheric aerosols is primarily motivated by their adverse effects on health and their contribution to the radiative budget of the 
atmosphere. Diseases affecting the respiratory system have been linked to the inhalation of aerosols, especially their finer and largest fraction (Beelen et al., 2014; Oberdorster, 2001), although the mechanisms underlying the health effect associated with the size, number and composition of particulate matter have only recently begun to be disclosed (Harrison and Yin, 2000; Daher et al., 2012; Perrone et al., 2013). Aerosols affect the atmospheric energy balance directly, by scattering and absorbing radiation (Yu et al., 2006), indirectly, by serving as cloud condensation nuclei (Lohmann and Feichter, 2005); and semi-directly, by heating the air through the absorption of radiation and reducing low cloud cover (Johnson et al., 2004). The assessment of these effects caused by aerosols is still characterized by large uncertainties, since our knowledge of the processes determining their abundance, size distribution and chemical composition, which strongly vary in space and time, is still limited (Raes et al., 2000; Pöschl, 2005). Here we focus on the interplay between dynamical and chemical processes in the vertical direction in order to better understand the budget terms making up the ground-level particulate matter, a common measure to evaluate air quality. The study focuses on the urban environment of Milan, situated in the centre of Italy's Po Valley, a European hot spot for atmospheric pollution.

The correlation between pollutants at the surface and meteorological variables is well established and the fundamental role played by the variables associated with the vertical mixing in the planetary boundary layer (PBL) has been highlighted both for ozone (Di Carlo et al., 2007, and references therein) and particulate matter (Tai et al., 2010, and references therein). Moreover, Zhang and Rao (1999) analysed aircraft and tower measurements over the eastern United States and showed that elevated nocturnal layers rich in ozone and its precursors aloft, remnants of the previous day's mixed layer, may strongly affect ground-level ozone levels on the following morning as vertical motions mix upper and surface air. The same authors suggested that a reduction of ozone and precursors aloft may be more effective in reducing pollution than local emission cuts, thus calling for a regionwide strategy for emissions control. Aerosols are also known to form layers above or near the top of the mixing layer, especially when the stability and presence of clouds increase (e.g. O'Dowd and Smith, 1996). Similarly to ozone, an aerosol residual layer aloft is often observed (e.g. Di Giuseppe et al., 2012), which may influence the aerosol at the surface, as witnessed by similar size distributions (Maletto et al., 2003). A significant contribution to surface aerosol from entrainment and vertical dilution and chemical net production in the boundary layer has also been pointed out in recent studies using single-column models (van Stratum et al., 2012; Ouwersloot et al., 2012).

The nontrivial relationship between ground- and upperlevel aerosol burdens is illustrated by comparing surface particulate matter (PM) mass concentrations to aerosol optical depth (AOD), which is proportional to the aerosol column load (typically measured by ground-based sun photometers or retrieved from satellites). In a well-mixed PBL, the AOD may exhibit a high correlation with surface PM, especially with its fine fraction, and indeed this assumption is often exploited to infer surface $\mathrm{PM}_{2.5}$ ( $\mathrm{PM}$ with diameter $<2.5 \mu \mathrm{m}$ ) from satellite AOD observations (e.g. van Donkelaar et al., 2010). However, that assumption does not always hold true, due to the presence of significant aerosol stratification aloft, and noticeable differences may occur between AOD and surface PM behaviour, such as in the timing of daily peak values or in multiday trends (Barnaba et al., 2007, 2010; Boselli et al., 2009; Estelles et al., 2012; He et al., 2012). Indeed, analysing 2-year measurements in the Po Valley (Italy), Barnaba et al. (2010) pointed out that annual cycles of AOD and surface $\mathrm{PM}_{10}(\mathrm{PM}$ with diameter $<10 \mu \mathrm{m})$ display a remarkable opposite phase. While $\mathrm{PM}_{10}$ peaks in winter, due to the reduced dilution by a shallower PBL and to the condensation of semi-volatile species favoured by the lower temperatures, AOD peaks in summer because of the more persistent presence of an aerosol residual layer aloft, which contributes up to $30 \%$ of the total AOD.

Aircraft measurements also showed intriguing features of aerosol vertical gradients in the lower troposphere, in particular when looking at different chemical components. Several studies reported a generally constant or slightly decreasing profile in the convective boundary layer of sulfate and organic matter as opposed to an increasing profile of nitrate (Neuman et al., 2003; Cook et al., 2007; Crosier et al., 2007; Morgan et al., 2009; Ferrero et al., 2012). Neuman et al. (2003) attributed the enhanced nitrate layer near the top of the PBL to the lower temperatures that favour gas-phase nitric acid $\left(\mathrm{HNO}_{3}\right)$ and ammonia $\left(\mathrm{NH}_{3}\right)$ conversion to particulate ammonium nitrate. The same authors also pointed out that nitrate and $\mathrm{HNO}_{3}$ display sharp vertical gradients in the PBL, as opposed to other directly emitted (carbon monoxide) or secondary (ozone) species that are relatively uniform, and this observation was interpreted as an indication that thermodynamic equilibrium between gas and particle phases occurs faster than vertical mixing. However, the issue is still under debate as subsequent model studies found that an instantaneous thermodynamic equilibrium between $\mathrm{HNO}_{3}$ and nitrate yields excessively steep and unrealistic vertical gradients (Morino et al., 2006; Aan de Brugh et al., 2012). Moreover, the presence of aerosol layers enriched with sulfate and water-soluble carbonaceous matter was observed above the boundary layer or in convective clouds during several aircraft campaigns over North America (Novakov et al., 1997; Heald et al., 2006; Duong et al., 2011; Wonaschuetz et al., 2012) and attributed to biomass burning plumes or aqueouschemistry processes.

A quantitative assessment of the contribution of elevated aerosol layers and related dynamical and chemical processes to ground-level particulate-matter level is still lacking. Recent modelling studies that reported budget (or process) analyses of the simulated aerosol mainly focused on terms of 
the continuity equation at the surface or on integrated values over the whole boundary layer. Surface and PBL total $\mathrm{PM}_{2.5}$ mass is calculated to be mainly produced by direct emissions and secondary formation by aerosol processes (e.g. condensation and absorption) and removed by horizontal and vertical transport and wet deposition (Zhang et al., 2009; Liu et al., 2011). The controlling processes are different for surface PM number, which is accumulated mainly by homogeneous nucleation and vertical transport, and it is lost mainly by dry deposition and coagulation (Zhang et al., 2010).

For primary components such as black carbon (BC), the fate is similar to that of total $\mathrm{PM}_{2.5}$, while for secondary species it is more intricate. Sulfate is generally produced in the PBL by aerosol and clouds processes (the latter being very important) and exported out of the PBL throughout the year (de Meij et al., 2007; Zhang et al., 2009; Aan de Brugh et al., 2011; Liu et al., 2011). Averaged over the year, the nitrate budget is similar to that of sulfate, with the difference that cloud processes (wet deposition) are a sink (Aan de Brugh et al., 2011; Liu et al., 2011). However, during the summer there might be competition between PM production (e.g. condensation and absorption) and destruction (e.g. evaporation and desorption) processes, and the PBL may become a sink and not a source for nitrate (Zhang et al., 2009). The same competition between PM production and destruction processes affects secondary organic aerosols (SOAs) throughout the year (Zhang et al., 2009). Moreover, SOAs are strongly influenced by biogenic volatile organic compound (BVOC) emissions, through semi-volatile products of isoprene and terpene oxidation, which also has a marked seasonal cycle (Zhang et al., 2007; Hodzic et al., 2009).

In the present study, we examined the formation of aerosol near the surface from the particular perspective of the boundary layer vertical processes outlined above. We analysed aerosol mass observations, composition, number and optical properties in the month of July 2007 in Milan $\left(45^{\circ} \mathrm{N}\right.$, $9^{\circ} \mathrm{E}$; northern Italy) during the intensive campaigns carried out within the framework of the QUITSAT (Air Quality by the Integration of Ground- and Satellite-based Observations and Multiphase Chemistry-Transport Modelling, funded by the Italian Space Agency, ASI) and AeroClouds (Study of Direct and Indirect Effect of Aerosols and Clouds on Climate, funded by the Italian Ministry for Higher Education) projects. The experimental results were then complemented by and interpreted through WRF/Chem (Weather Research and Forecasting with Chemistry) model simulations.

Firstly, what is known about the aerosol phenomenology in the investigated area is briefly reviewed in Sect. 2. We describe the experimental set-up in Sect. 3 and the model set-up in Sect. 4. In Sect. 5, a preliminary analysis of the observations is carried out in order to characterize the relevant features of the case study and pose questions arising from the picture given by the measurements. Then, these questions are addressed using WRF/Chem model simulations. After a model validation against available observations, we analyse the budget of aerosol species as calculated by the model, focusing in particular on the vertical dimension. The main results are summarized in the conclusion.

\section{The investigated area}

Milan is the largest urban area in Italy (ca. 5 million people) and lies in one of the most polluted areas in Europe, the Po Valley (Putaud et al., 2010). The topography of the valley (closed off by the Alps to the north and west and by the Apennines to the south), under high-pressure systems, favours stagnant atmospheric conditions and the recirculation of air through the typical mountain-valley breeze (Dosio et al., 2002). The local circulation in combination with elevated anthropogenic emissions especially from traffic, residential combustion and agriculture (Lonati et al., 2005; Carnevale et al., 2008; Perrone et al., 2012; Saarikoski et al., 2012) makes it a nitrogen dioxide and aerosol hot spot clearly visible from space (e.g. Chu et al., 2003; Barnaba and Gobbi, 2004; Ordonez et al., 2006; van Donkelaar et al., 2010).

At the surface, the $\mathrm{PM}_{10}$ annual mean in Milan has been stable between 50 and $60 \mathrm{\mu g} \mathrm{m}^{-3}$ in the last decade (Carnevale et al., 2008; Silibello et al., 2008), it has thus been systematically above the European limit for human protection of $40 \mu \mathrm{g} \mathrm{m}^{-3}$ (EC, 2008). The winter average values are roughly double those in the summer, and peak values are up to $200 \mathrm{~g} \mathrm{~m} \mathrm{~m}^{-3}$ (Marcazzan et al., 2001). The main aerosol components are sulfate, nitrate and organic matter (OM), which account for roughly 20, 15 and $40 \%$, respectively, of $\mathrm{PM}_{10}$ mass in summer and 10, 30 and $50 \%$, respectively, in winter (Marcazzan et al., 2001; Putaud et al., 2002; Lonati et al., 2005; Carbone et al., 2010; Perrone et al., 2010; Daher et al., 2012). These values are similar to those in other urban areas in the Po Valley (Matta et al., 2003; Carbone et al., 2010; Squizzato et al., 2013). Most of the mass of these species is distributed in the accumulation mode (particle diameter in the range $0.14-1.2 \mu \mathrm{m})$, while the coarse mode $(1.2-10 \mu \mathrm{m}$ diameter) has a larger fraction of crustal material and sea salts (Matta et al., 2003; Carbone et al., 2010). In summer, nitrate can exhibit a broader size distribution as a larger fraction may also form in the coarse mode. Higher temperatures, lower humidity and a higher load of sulfate competing for the uptake of ammonia are less favourable to ammonium nitrate accumulation in the fine mode. As a consequence, more nitric acid is available to react with soil dust or sea salt, leading to the formation of mineral nitrate on coarse particles. (Matta et al., 2003; Hodzic et al., 2006; Lee et al., 2008; Carbone et al., 2010). The total number concentration of aerosol is of the order of $10^{4} \mathrm{~cm}^{-3}$, with ultrafine (diameter $d<100 \mathrm{~nm}$ ) and submicron $(100<d<1000 \mathrm{~nm})$ particles constituting up to 80 and $20 \%$ of the total, respectively (Lonati et al., 2011). The aerosol number concentration is usually distributed in three modes (Balternsperger et al., 2002; Lonati et al., 2011). One mode, with diameters in the range of $20-30 \mathrm{~nm}$ consists 
of hydrophobic and highly volatile organic material originating from combustion (Baltensperger et al., 2002), plus new particles from nucleation events that occur on about $35 \%$ of the days in the Po Valley (Hamed et al., 2007). The other two modes are in the submicron range (dry diameters 50$200 \mathrm{~nm}$ ): one is almost hydrophobic, related to primary emissions (e.g. soot), and the other is hydrophilic, related to secondary aerosols (Balternsperger et al., 2002).

The aerosol vertical profile in Milan and in the wider Po Valley region was characterized by means of aircraft, lidar and tethered balloon measurements (Highwood et al., 2007; Barnaba et al., 2007, 2010; Crosier et al., 2007; Angelini et al., 2009; Ferrero et al., 2010, 2011). Similarly to other polluted valley areas, two layers with distinct characteristics are often found: one in the PBL, which is humid, rich in fresh emissions and has a nitrate profile increasing with height, and another layer, above the PBL, with more aged aerosols enriched in the sulfate and organic matter fraction (Highwood et al., 2007; Crosier et al., 2007; Ferrero et al., 2010). This decoupling into two layers is attributed to the mountainvalley breeze dynamics (Angelini et al., 2009) and to the sporadic arrival of long-range transported Saharan dust (Barnaba et al., 2007) or biomass burning plumes (Barnaba et al., 2011). The number concentration of fine-mode $(d<1.6 \mu \mathrm{m})$ particles is found to be relatively constant with height in the PBL, and it decreases by a factor of 2-3 above the PBL. In contrast, coarse-particle $(d>1.6 \mu \mathrm{m})$ number concentrations display a decrease with height also in the PBL, due to sedimentation processes (Ferrero et al., 2010).

\section{Experimental set-up}

Ground-based and vertical profile measurements used in this study were conducted at the Torre Sarca site, which is located on the northern side of Milan $\left(45^{\circ} 31^{\prime} 19^{\prime \prime} \mathrm{N}, 9^{\circ} 12^{\prime} 46^{\prime \prime} \mathrm{E}\right.$; within the Milano-Bicocca University campus), in the midst of an extensive conurbation that is the most industrialized and heavily populated area in the Po Valley. We report here a brief description of the experimental set-up and provide relevant references for further details.

\subsection{Particulate-matter bulk composition and number size distribution as well as gas-phase composition}

At ground level, $\mathrm{PM}_{2.5}$ and $\mathrm{PM}_{1}(\mathrm{EN}-14907)$ samples were gravimetrically collected using the FAI Hydra dual-channel low-volume sampler (LVS; $2.3 \mathrm{~m}^{3} \mathrm{~h}^{-1}, 24 \mathrm{~h}$ of sampling time, PTFE filters for $\mathrm{PM}_{1}$ ore-fired quartz fibre filters for $\mathrm{PM}_{2.5}, \varnothing=47 \mathrm{~mm}$ ), while the aerosol number size distribution was constantly monitored using an optical particle counter (OPC; Grimm 1.107 "Environcheck", 31 class sizes ranging from 0.25 to $32 \mu \mathrm{m}$ ). Further details are given in Ferrero et al. (2014).
The aerosol chemistry was assessed on $\mathrm{PM}_{2.5}$ samples for the ionic fraction, elemental carbon (EC) and organic carbon (OC). For the purpose of ion analysis, $\mathrm{PM}_{2.5}$ samples were extracted in $3 \mathrm{~mL}$ of ultrapure water (Milli-Q ${ }^{\circledR}$; $18.2 \mathrm{M} \Omega \times \mathrm{cm}$ ) for $20 \mathrm{~min}$ using an ultrasonic bath (SONICA, Soltec, Italy). The obtained solutions were then analysed using a coupled ion chromatography system consisting of (1) a Dionex ICS-90 (CS12A-5 analytical column) with an isocratic elution of methanesulfonic acid $\left(20 \mathrm{Mm} ; 0.5 \mathrm{~mL} \mathrm{~min}^{-1}\right)$ whose signal was suppressed by means of tetrabutylammonium hydroxide $(0.1 \mathrm{M}$; CMMS III $4 \mathrm{~mm}$ MicroMembrane Suppressor) for cations $\left(\mathrm{Na}^{+}\right.$, $\mathrm{K}^{+}, \mathrm{Ca}^{++}, \mathrm{Mg}^{++}, \mathrm{NH}_{4}^{+}$) and (2) a Dionex ICS-2000 (AS14A-5 analytical columns) with an isocratic solution of $\mathrm{Na}_{2} \mathrm{CO}_{3} / \mathrm{NaHCO}_{3}\left(8.0 \mathrm{mM} / 1.0 \mathrm{mM} ; 1 \mathrm{~mL} \mathrm{~min}^{-1}\right)$ whose signal was suppressed by means of sulfuric acid $(0.05 \mathrm{M}$; AMMS III $2 \mathrm{~mm}$ MicroMembrane Suppressor) for anions $\left(\mathrm{F}^{-}, \mathrm{Cl}^{-}, \mathrm{NO}_{3}^{-}, \mathrm{SO}_{4}^{=}\right)$.

EC and OC were determined in $\mathrm{PM}_{2.5}$ using the thermaloptical transmission method (TOT, Sunset Laboratory Inc.; NIOSH 5040 procedure, http://www.cdc.gov/niosh/nmam/ pdfs/5040f3.pdf). The organic matter (OM) fraction was then estimated from OC using a coefficient to account for the presence of heteroatoms ( $\mathrm{H}, \mathrm{O}, \mathrm{N}$, etc.). Following the work of Turpin and Lim (2001), the factor chosen was 1.6 for the urban Torre Sarca site.

Finally, meteorological and gas-phase $\left(\mathrm{NO}_{\mathrm{x}}, \mathrm{O}_{3}\right)$ observations at ground level were taken from the weather and monitoring stations operated in Milan by the local regional environmental protection agency (ARPA Lombardia).

\subsection{Size-segregated aerosol composition}

From 14 (08:00 local time LT) to 18 (08:00 LT) July 2007, size segregated daytime (08:00 to 21:00 LT) and night-time (21:00 to 08:00 LT) aerosol samples were collected by means of a five-stage Berner impactor (LPI 80/0.05) with a $50 \%$ efficiency size cut at $0.05,0.14,0.42,1.2,3.5$ and $10 \mu \mathrm{m}$ aerodynamic diameter. Substrates were analysed off-line for the determination of the carbonaceous - water-soluble organic (WSOC) and water-insoluble (WINC) carbon - and soluble inorganic components $\left(\mathrm{NH}_{4}^{+}, \mathrm{Na}^{+}, \mathrm{K}^{+}, \mathrm{Ca}^{2+}, \mathrm{Mg}^{2+}\right.$, $\mathrm{Cl}^{-}, \mathrm{NO}_{3}^{-}, \mathrm{SO}_{4}^{2-}$ ). Mass-to-carbon ratios of 1.8 and 1.2 were used to convert WSOC to the corresponding mass and to convert WSOM (water-soluble organic matter) and WINC to WINCM (water-insoluble carbonaceous matter), respectively. A complete description of the sampling and analytical methods adopted is reported in Carbone et al. (2010) and references therein. In the analysis presented here, we only used the total mass of aerosol components (sum over size bins).

\subsection{Lidar-ceilometer profiles}

Lidar ceilometers (called lidar for brevity in this paper) operate on the same physical basis of more complex research- 
type lidars but are compact systems, generally with a lower laser energy power, capable of operating $24 \mathrm{~h}$ per day, unattended and in all weather conditions. Initially developed for cloud-base determination, the technology of these systems is now mature enough to represent a very convenient and widely used tool for the operational monitoring of atmospheric aerosol and of relevant meteorological parameters (e.g. Haeffelin et al., 2012).

A lidar ceilometer (Vaisala LD-40) operating at $855 \mathrm{~nm}$ collected aerosol profiles at the Milan Torre Sarca site in the January 2007-February 2008 period. The system was switched on on selected dates (and mostly when meteorological conditions allowed the simultaneous launch of balloonborne aerosol instruments; Ferrero et al., 2010), collecting a database of more than 200 days of measurements. On the selected dates, the lidar ceilometer operated $24 \mathrm{~h}$ per day, collecting aerosol profiles every $15 \mathrm{~s}$; these were afterwards averaged over $15 \mathrm{~min}$ to achieve a better signal-to-noise ratio. Due to the instrumental limitations, the lowest altitude the system can observe is about $60 \mathrm{~m}$. After the background noise is subtracted from the collected backscattered signal, the range-corrected signal (RCS, i.e. the signal $S$ times the square of the system-to-target distance $R$ ) is derived to extract information on the aerosol vertical distribution. More details on the system and measurement capabilities can be found in Angelini et al. (2009) and Di Giuseppe et al. (2012).

\section{WRF/Chem model}

\subsection{Description and set-up}

The 3.4.1 version of WRF/Chem, with some updates, is used in order to interpret the observed concentrations of aerosol and its composition at the surface and along the vertical profile of the PBL. WRF/Chem is a coupled online model, in which meteorological and chemical processes are fully consistent (Grell et al., 2005).

The model is configured with two one-way nested domains centred on northern Italy (Po Valley). The mother domain covers western Europe, with $131 \times 95$ cells at a horizontal resolution of $30 \mathrm{~km}$; the nested domain covers northern Italy, with $109 \times 91$ cells at a resolution of $10 \mathrm{~km}$. The vertical grid is made of 33 eta levels up to $50 \mathrm{hPa}$, with the first five levels centred approximately at $12,36,64,100$ and $140 \mathrm{~m}$ above the ground and 12 levels below $1 \mathrm{~km}$.

The physical and chemical parameterizations used are the same for the two domains and are listed in Table 1. These include the rapid radiative transfer model for short- and longwave radiation (Iacono et al., 2008), the Mellor-Yamada Nakanishi-Niino boundary layer parameterization (Nakanishi and Niino, 2006), the Noah Land Surface Model (Chen and Dudhia, 2001), the Morrison cloud microphysics scheme (Morrison et al., 2009) and the Grell 3-D ensemble cumulus scheme, which is an updated version of the Grell-Devenyi
Table 1. Main physical and chemical parameterizations used in WRF/Chem simulations. For definition of acronyms please refer to main text.

\begin{tabular}{ll}
\hline Process & Scheme \\
\hline Short-wave radiation & RRTM \\
Long-wave radiation & RRTM \\
Surface layer & Monin-Obukhov \\
Boundary layer & MYNN \\
Land surface model & Noah LSM \\
Cumulus convection & Grell scheme G3 \\
Cloud microphysics & Morrison \\
Gas-phase mechanism & RACM-ESRL \\
Aerosol mechanism & MADE/SOA-VBS \\
Photolysis & Fast-J \\
Cloud chemistry and wet deposition & On \\
Biogenic emissions & MEGAN \\
Direct aerosol effect & On \\
Indirect aerosol effects & Off \\
\hline
\end{tabular}

scheme (Grell and Devenyi, 2002). Cumulus cloud feedback with radiation is activated.

The gas-phase chemistry is simulated with an updated version of the Regional Atmospheric Chemistry Mechanism (RACM), which includes a wide range of chemical and photolytic reactions for organic and inorganic species (Stockwell et al., 1997). The aerosol parameterization adopted is the Modal Aerosol Dynamics for Europe (Ackermann et al., 1998), which uses three overlapping lognormal modes for Aitken, accumulation and coarse particles. Thermodynamic equilibrium for inorganic species is calculated using the Model for an Aerosol Reacting System (MARS) module (Saxena et al., 1986; Binkowski and Roselle, 2003). SOA production is calculated using the volatility basis set (VBS) scheme implemented in WRF/Chem by Ahmadov et al. (2012), which includes the oxidation of anthropogenic and biogenic volatile organic compounds (VOC) currently believed to be important for SOA production (alkanes, alkenes, xylenes, aromatics, isoprene, monoterpenes and sesquiterpenes). To our knowledge, this study is the first application over Europe of this new parameterization for SOA yield by means of WRF/Chem. Photolysis rates are estimated with the Fast-J scheme (Wild at al., 2000). The dry deposition flux is simulated with the scheme by Wesely et al. (1989), and the dry deposition velocity of organic vapours is assumed to be the $25 \%$ that of nitric acid $\left(\mathrm{HNO}_{3}\right)$. Cloud chemistry in convective updraft is parameterized following Walcek and Taylor (1986). Wet deposition due to convective and large-scale precipitation is also included in our simulations. The aerosol optical properties are calculated online with the package by Barnard et al. (2010), using the volume average internalmixing assumption. We included the direct effect of aerosol on radiation, but the indirect aerosol effects on clouds were 
switched off since this function is still under testing with the SOA VBS scheme (Tuccella et al., 2015).

In order to enhance our understanding of the influence of the upper-level processes on the pollutant budget at the surface, we use the diagnostic of the tendency terms in the continuity equation for chemical species following Wong et al. (2009). We extended the original module, which included only some gas-phase compounds, to include aerosol species and processes as well. Diagnosed terms are emission, horizontal and vertical advection, photochemistry (gases and aerosols), vertical mixing plus dry deposition (these cannot be separated in the WRF/Chem implementation), convective transport, aqueous chemistry, and wet deposition.

We have simulated the period from the 25 June to the 18 July 2007, discarding the first 10 days as spin-up. Simulation on the mother domain uses initial and boundary meteorological conditions provided by the National Centers for Environmental Prediction (NCEP) 6-hourly analyses, having a horizontal resolution of $1^{\circ} \times 1^{\circ}$. For the mother domain, chemical boundary conditions are provided with WRF/Chem default idealized vertical profiles, representative of northern hemispheric, midlatitude and clean environmental conditions (McKeen et al., 2002; Grell et al., 2005; Tuccella et al., 2012), while boundary conditions for the nested domain are provided by the mother domain. The simulations are carried out in $24 \mathrm{~h}$ time segments, starting at 12:00 UTC of each day and then run for $30 \mathrm{~h}$, with the first $6 \mathrm{~h}$ considered as model spin-up. Chemical fields are restarted from previous runs.

\subsection{Emissions}

Total annual 2007 anthropogenic emissions of nitrogen oxides $\left(\mathrm{NO}_{\mathrm{x}}\right)$, carbon monoxide $(\mathrm{CO})$, sulfur oxides $\left(\mathrm{SO}_{\mathrm{x}}\right)$, ammonia $\left(\mathrm{NH}_{3}\right)$, non-methane volatile organic compounds (NMVOC), unspeciated particulate matter $\left(\mathrm{PM}_{2.5}\right.$ and coarse $\mathrm{PM}$ ), primary organic carbon (OC) and elemental carbon (EC) are taken from the Netherlands Organization for Applied Scientific Research (TNO) database (Kuenen et al., 2014). Annual TNO anthropogenic emissions consist of gridded data from 10 source types (SNAP sectors), with a horizontal resolution of $1 / 16^{\circ}$ latitude by $1 / 8^{\circ}$ longitude (about $7 \times 7 \mathrm{~km}^{2}$ ).

TNO emissions are adapted to WRF/Chem following the methodology used by Tuccella et al. (2012), with minor changes derived from the second phase of the Air Quality Modelling Evaluation International Initiative (AQMEII) (Alapaty et al., 2012; Im et al., 2014a, b).

Biogenic emissions are calculated online using the Model of Emissions of Gases and Aerosols from Nature (MEGAN) (Guenther et al., 2006). Sea salt flux is calculated online, while dust source is not included.

\section{Results}

\subsection{Preliminary analysis of the observations}

In Fig. 1 time series of ground-based meteorological and physicochemical observations performed in Milan in the 520 July 2007 period are shown. The large-scale circulation is illustrated in Fig. S1 in the Supplement, while the evolution of cloud cover over northern Italy is illustrated by MODISAqua true-colour images in Fig. S2. The period starts with a low-pressure system over Germany, rapidly moving eastward and allowing a pressure increase over northern Italy from 5 to $8 \mathrm{July}$, associated with fair weather and sparse cloud cover. From 9 to 11 July, a North Atlantic low-pressure system induces a significant increase of cloud cover over Milan with light rain on 10 July. From 12 July, a wide anticyclonic system forms over the western Mediterranean, leading to clearsky and stable conditions until 20 July and later. Maximum daily temperature is around $30^{\circ} \mathrm{C}$ before the Atlantic perturbation; then it increases steadily (from 25 to $35^{\circ} \mathrm{C}$ ) at a rate of $\sim 2^{\circ}$ day $^{-1}$ from 11 to 15 July as the high-pressure system settles. Humidity is high at night (above $70 \%$ ) on the days following the low-pressure passage; then the atmosphere gradually dries out under the anticyclone.

During the period preceding the Atlantic perturbation (58 July 2007), wind is prevalently a westerly wind during the daytime, forced by the large-scale circulation and with a wind speed of around $2.5-3 \mathrm{~m} \mathrm{~s}^{-1}$. Wind is slowed down to less than $1 \mathrm{~m} \mathrm{~s}^{-1}$ at night because the downward transport of momentum toward the surface is inhibited by the nighttime vertical stratification (Stull, 1988; Whiteman, 1990). Wind speed increases up to $5 \mathrm{~m} \mathrm{~s}^{-1}$ at the passage of the lowpressure system (9-11 July 2007), and it stays above $2 \mathrm{~m} \mathrm{~s}^{-1}$ also at nighttime. From 11 July, when the high-pressure over the Mediterranean begins to settle, the wind field adjusts to a typical mountain-valley breeze regime (Whiteman, 1990). Starting from midnight, the slow $\left(\sim 1 \mathrm{~m} \mathrm{~s}^{-1}\right)$ northerly flow gradually accelerates and rotates clockwise, reaching peak speeds of $\sim 3 \mathrm{~m} \mathrm{~s}^{-1}$ in the afternoon in a south-westerly direction, then gradually slows down and return to a northerly direction. This wind pattern favours conditions of stagnation and recirculation of air within the valley, allowing the buildup of pollutants from one day to the next. Figure S3 shows the simple stagnation and recirculation indices proposed by Allwine and Whiteman (1994) and confirms that the only ventilated period is that of the Atlantic perturbation.

The passage of the Atlantic low-pressure system on 910 July marks a sort of "restart" for the atmospheric composition at ground level. Indeed, relatively longer-lived (few days) chemical species, such as ozone and PM, first accumulate during the days preceding the perturbation; they are then suppressed in perturbed weather and finally re-accumulate afterwards (Fig. 1c, d). Outside the perturbed period, ozone and nitrogen oxides $\left(\mathrm{NO}_{\mathrm{x}}\right)$ follow a daily cycle typical of that observed in many urban areas (Mavroidis and Ilia, 2012, and 


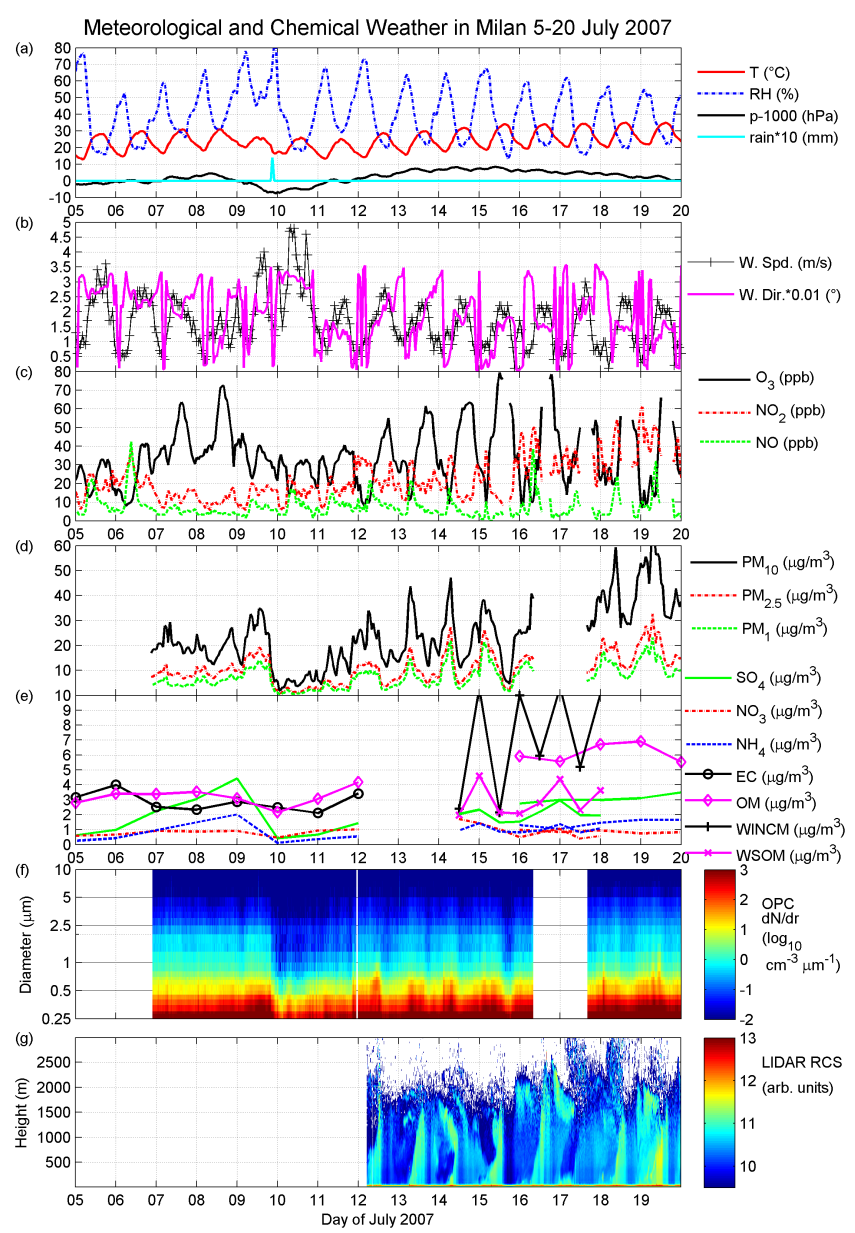

Figure 1. Ground-based observations in Milan during 5-20 July 2007. Panel (a) shows hourly measurements of temperature, relative humidity, pressure and precipitation. Pressure is pressure minus 1000 , and precipitation is multiplied by 10 in order to fit the same $y$ axis. (b) Hourly wind speed and wind direction $\left(0^{\circ}\right.$ from the north, $90^{\circ}$ from the east), the latter divided by 100 to fit the same $y$ axis. (c) Hourly ozone, nitrogen dioxide and nitrogen oxide. (d) Particulate-matter mass. Hourly observations of $\mathrm{PM}_{10}, \mathrm{PM}_{2.5}$, and $\mathrm{PM}_{1}$. (e) Particulate-matter composition. Daily data for sulfate, nitrate, ammonium, elemental carbon and organic matter collected during QUITSAT campaign. Night-time (21:00 to 08:00 LST) and daytime (08:00 to 21:00 LST) samples of sulfate, nitrate, ammonium, water-insoluble carbonaceous matter (WINCM) and watersoluble organic matter (WSOM) collected during AeroClouds campaign (14-17 July). (f) Particulate-matter number size distribution; optical particle counter (OPC) hourly average measurements; $y$ axis denotes the size bin. (g) Particulate-matter vertical profile; lidar range-corrected signal; $y$ axis denotes the height above ground level.

references therein). The primary pollutant nitric oxide (NO) displays a sharp peak during morning rush hours (between 06:00 and 09:00 local solar time), then gradually decreases during the day. It displays a secondary small peak during evening rush hours (20:00-22:00 LST), then remains at low values until the following morning. Nitrogen dioxide $\left(\mathrm{NO}_{2}\right)$ mainly originates from the oxidation of $\mathrm{NO}$ by ozone and peroxy radicals (Jenkin and Clemitshaw, 2000) and displays peaks delayed by $\sim 1 \mathrm{~h}$ with respect to those of NO. It shows a plateau between the morning and the evening peak because concentrations are sustained during the daytime by photochemistry. The photolysis of $\mathrm{NO}_{2}$ is the main tropospheric source of atomic oxygen $(\mathrm{O})$ that readily reacts with molecular oxygen $\left(\mathrm{O}_{2}\right)$ to produce ozone. Indeed, during daylight hours, $\mathrm{NO}, \mathrm{NO}_{2}$ and $\mathrm{O}_{3}$ equilibrate on the so-called "photostationary equilibrium" on timescales of minutes (Clapp and Jenkin, 2001).

Ozone is depleted during the morning rush hours by reaction with NO; then it is photochemically formed during the day, peaks during the late afternoon (14:00-16:00 LST) and thereafter gradually decreases to lower nighttime levels. In fair weather, the daily cycle of ozone and $\mathrm{NO}_{\mathrm{x}}$ is regulated by the solar radiation, the dilution of fresh emissions from the surface in the growing daytime PBL, the vertical mixing with air entrained from the residual layer and the free troposphere above the PBL and the dry deposition at the surface. Past studies pointed out that the entrainment from ozone-rich residual layer may be as important as the photochemical production in the PBL during pollution events even in urban atmospheres (e.g. Zhang and Rao, 1999). In the present case, the build-up of ozone in the days following the perturbation is evident, but it is difficult to discern the relative role played by the local photochemical production and by the vertical mixing regarding the ozone trend observed at the surface.

Accumulation and cleansing of the atmosphere near the surface is even more evident from aerosol time series (Fig. 1d-g). $\mathrm{PM}_{2.5}$ and $\mathrm{PM}_{1}$ follow a similar trend, while $\mathrm{PM}_{10}$ often shows a different behaviour, pointing to the presence of additional sources for the coarse fraction, most probably the erosion and resuspension of soil material by vehicles and wind. The aerosol mass is shown to build up before the Atlantic perturbation $\left(\mathrm{PM}_{10}\right.$ around $\left.20-30 \mu \mathrm{g} \mathrm{m}^{-3}\right)$ and to abruptly decrease $\left(\mathrm{PM}_{10}\right.$ below $\left.10 \mu \mathrm{g} \mathrm{m}^{-3}\right)$ during the lowpressure system passage (probably because of a combination of enhanced ventilation, wet deposition processes and soil erosion inhibited by increased soil moisture). Afterwards, PM concentration keeps increasing after the low-pressure passage (maximum $\mathrm{PM}_{10}$ values of more than $60 \mu \mathrm{g} \mathrm{m}^{-3}$ reached on 18-19 July). The daily cycle of the fine aerosol mass $\left(\mathrm{PM}_{2.5}\right.$ and $\left.\mathrm{PM}_{1}\right)$ displays similarities with that of $\mathrm{NO}$, in particular a similar morning peak, indicating the important role played by primary emissions. This is confirmed by the analysis of aerosol speciation (Fig. 1e), which shows high values of elemental carbon (EC, $2-4 \mu \mathrm{g} \mathrm{m}^{-3}$ ) and insoluble carbonaceous matter (WINCM, 2-10 $\mu \mathrm{g} \mathrm{m}^{-3}$ ). The latter makes, on average, $40-50 \%$ of the $\mathrm{PM}_{1}$ mass (Carbone et al., 2010). Major secondary species are inorganic ions (sulfate, nitrate and ammonium) and part of the organic matter, which may be associated with its water-soluble fraction (WSOM, Carbone et al., 2010). Similarly to ozone, sec- 
ondary aerosol accumulates during the days preceding and following the perturbation.

The cleansing of the atmosphere after the perturbation and subsequent recovery of the aerosol load is also clearly visible in the number concentration time series. At the passage of the perturbation, the aerosol number rapidly decreases by more than 1 order of magnitude at all observed size ranges, then returns to the preperturbation levels on a timescale of about 2 days. We note, however, differences in the aerosol regime before and after the perturbation. Before the cleansing, the aerosol size distribution is locked into a fixed shape, with no or little daily variability. Conversely, in the stable conditions of 12-19 July, it displays a clear daily cycle with a growth towards larger sizes in daytime and a return to narrower distributions at nighttime.

As mentioned in Sect. 3.3, lidar observations are only available in the days following the perturbation and give useful indications of the aerosol vertically resolved infra- and inter-diurnal variability (e.g. Angelini et al., 2009). During the morning hours, a layer of aerosol is formed under the growing boundary layer. There, fresh emissions from the surface are diluted and mixed vertically in the PBL. Throughout the period, but especially on some days, such as 13 and 15 July in the morning, an enhanced layer of aerosol is visible in the upper levels near the top of the PBL. Aerosol is subsequently partly removed in the second half of the day by the mountain breeze, while a residual layer with relatively high aerosol content may survive above the nocturnal PBL (e.g. on 13,15 , and 16 July). This layer may potentially be entrained the following morning into the PBL and contribute to the surface aerosol budget. On the last days displayed in Fig. 1, a further aerosol layer between 2 and $3 \mathrm{~km}$ appears in the lidar signal. As indicated by increased coarse-fraction AOD at the Modena AERONET (AErosol RObotic NETwork) station (Fig. S4) and model back trajectories (Fig. S5), this is a Saharan dust incursion which is probably entrained at ground level, as indicated by the enhancement of $\mathrm{PM}_{10}$ levels on 1819 July. Since Saharan dust intrusions are not modelled here, these days are excluded from the analysis.

From the measurements reported here some questions emerged:

1. What is the composition of the aerosol layer formed during the day in the upper PBL?

2. How much of the aerosol burden measured on the ground is due to localized processes and, conversely, how much is due to processes occurring in the upper PBL and to the subsequent mixing in the lowermost levels? In other words, how important is the interplay between surface and upper layers in shaping the aerosol mass we measure near the ground?

3. How much may the residual layer above the PBL contribute to the aerosol budget at ground level the next day?

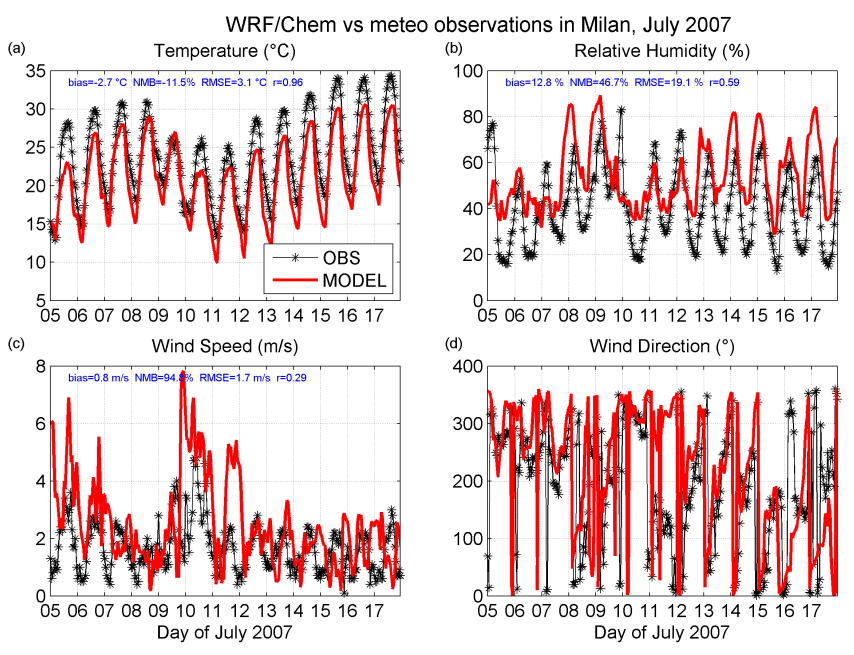

Figure 2. Comparison of observed and simulated hourly meteorological variables at ground level in Milan on 5-17 July 2007. Simulations are carried out with WRF/Chem model and results are shown for the nested domain over northern Italy at a $10 \mathrm{~km}$ horizontal resolution. Statistical indices shown in the inset are defined in Appendix A.

We attempted to provide answers to these questions using simulations with the WRF/Chem model and relevant comparisons with the observational data set.

\subsection{Model verification against available observations}

Before drawing conclusions on the scientific questions outlined at the end of the previous section, we verified our model simulations against the data set of observations depicted in Fig. 1 and only displayed results for the nested domain over northern Italy, using statistical indices defined in Appendix A as a guidance to quantify model biases.

In Fig. 2 we compared, observed and simulated hourly meteorological variables at ground level in Milan on 5-17 July 2007. Simulations are carried out with the WRF/Chem model, and results are shown for the nested domain over northern Italy at a $10 \mathrm{~km}$ horizontal resolution. Statistical indices shown in the inset are defined in Appendix A. We compared observed and simulated meteorological variables at ground level in Milan for the period 5-17 July 2007. The temperature is underestimated by about $2.5^{\circ} \mathrm{C}$, which is probably due to poorly resolved dynamics and heat fluxes in the urban boundary layer. The overestimation of relative humidity by about $10 \%$ is mostly attributable to the underestimation of temperature. Wind speed at $10 \mathrm{~m}$ is overestimated by $0.8 \mathrm{~m} \mathrm{~s}^{-1}$ and has a relatively low correlation of 0.29 with observations, thus fitting the typical characteristics of current mesoscale models (e.g. Misenis and Zhang, 2010). The simulated wind speed is also more variable than that observed as indicated by the root mean square error (RMSE) of $1.7 \mathrm{~m} \mathrm{~s}^{-1}$. The wind direction is generally captured well, in 


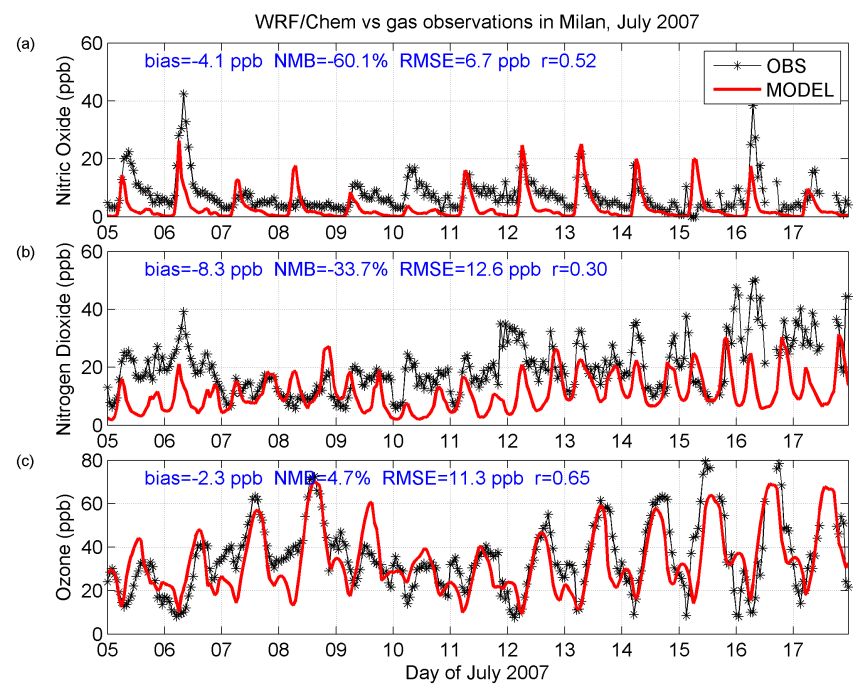

Figure 3. Same as Fig. 2 but for hourly gas-phase variables at ground level in Milan on 5-17 July 2007. Shown in the inset are statistical indices defined in Appendix A.

particular the mountain-valley cycles after the passage of the perturbation of 9 July.

In Fig. 3 we show a comparison of gas-phase observations and simulations near the ground. The daily cycle of NO is reproduced well $(r=0.52)$; the timings of the morning peak and the subsequent decrease are captured by the model. The magnitude of the morning peak does not show a tendency to underestimate nor to overestimate, while NO values for the rest of the day are underestimated, resulting in a bias of $-4.1 \mathrm{ppb}(-60 \%)$. The model is also able to capture the basic features of the $\mathrm{NO}_{2}$ daily cycle, i.e. the morning and evening peaks and the minimum at night. However, values are generally underestimated (bias of $-8.3 \mathrm{ppb}$ or $-34 \%$ ), and the trend on weekly timescale displays much less variability than that observed. Ozone displays a very low systematic bias $(-2.3 \mathrm{ppb})$, but less variability than observations (RMSE of $11.3 \mathrm{ppb}$ ), and a correlation of 0.65 . The timing of the daily cycle is captured well, with a maximum in the afternoon, a secondary peak around midnight and a minimum during the morning rush hour.

In Fig. 4 we compare $\mathrm{PM}_{10}$ and $\mathrm{PM}_{2.5}$ simulated mass to hourly observations at ground level. The $\mathrm{PM}_{10}$ trend is qualitatively captured by the model, displaying the sharp decrease at the passage of the perturbation on 10 July and the subsequent gradual accumulation in the following days. This provides confidence in the simulated removal and production terms, and the resulting negative bias is low $\left(-4 \mu \mathrm{g} \mathrm{m}^{-3}\right.$ or $-10 \%)$. The model also captures some of the characteristics of the daily cycle $(r=0.57)$; however, the observed signal is quite irregular, and the model does not reproduce all the variability. The negative bias of $\mathrm{PM}_{10}$ could be partly explained by the missing source for soil dust erosion and resuspension caused by traffic in the model. For $\mathrm{PM}_{2.5}$ the general features

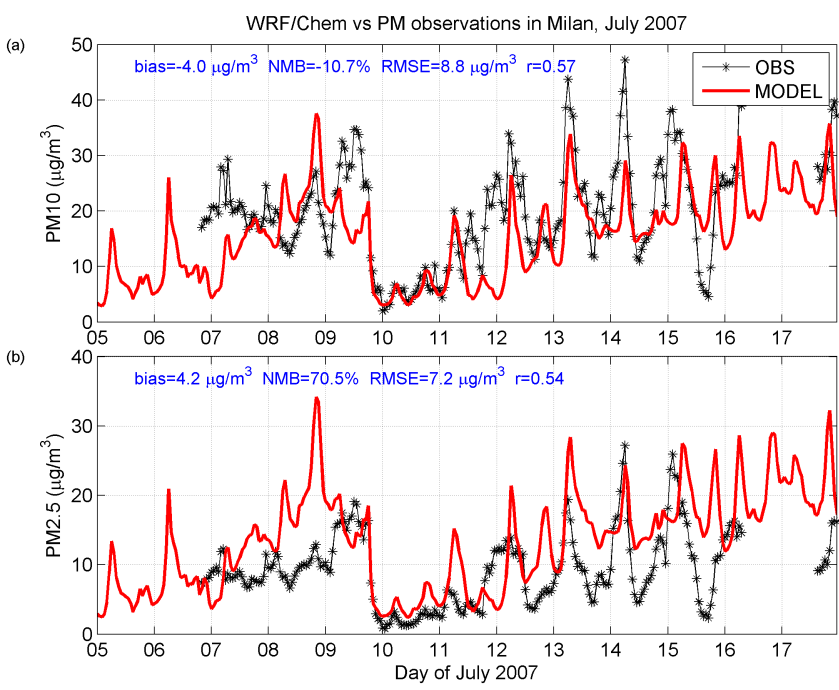

Figure 4. Same as Fig. 2 but for hourly particulate matter at ground level in Milan on 5-17 July 2007. Shown in the inset are statistical indices defined in Appendix A.

of the comparison are similar to $\mathrm{PM}_{10}$, but the model has a positive bias $\left(+4 \mu \mathrm{g} \mathrm{m}^{-3}\right.$ or $\left.+70 \%\right)$, mostly attributable to a few spurious peaks in the simulation. The overestimation of $\mathrm{PM}_{2.5}$ partly compensates for and masks the underestimation of coarse particles $\left(\mathrm{PM}_{2.5-10}\right)$. The comparison of the simulated number size distribution against that observed with the OPC (not shown) suggests that the high bias of $\mathrm{PM}_{2.5}$ is attributable to aerosol in the size range of $0.5-1 \mu \mathrm{m}$.

In Fig. 5 we show the comparison of simulated $\mathrm{PM}_{2.5}$ composition with daily and twice-daily samplings near the ground. In the period preceding the perturbation (5-9 July), the model underestimates the magnitude of the observed peak of sulfate and ammonium, but it reproduces the subsequent restart and recovery well. Observed nitrate displays little variability, with a slight decrease at the passage of the perturbation and almost constant levels during the rest of the period. Modelled nitrate has a much more variable behaviour, which seems to be characterized by sudden and irregular pulses. Indeed, the observations recorded twice a day suggest that the daily average observation masks much of the underlying variability associated with nitrate. Recently reported hourly measurements of PM composition in the Po Valley did in fact confirm the same "pulsed" behaviour of nitrate near the ground, with values near 0 during daytime, and irregular peaks at nighttime (Decesari et al., 2014). This highlights the inherent difficulties in simulating the nitrate concentrations at a sub-daily frequency. Elemental carbon, being primary and almost hydrophobic, is largely unaffected by the perturbation. This feature is captured by the model, but $\mathrm{EC}$ values are underestimated by a factor of 2, probably due to underestimated emissions. Interestingly, the observations of WINCM (EC plus primary insoluble organic material) recorded twice a day display a large diurnal cy- 

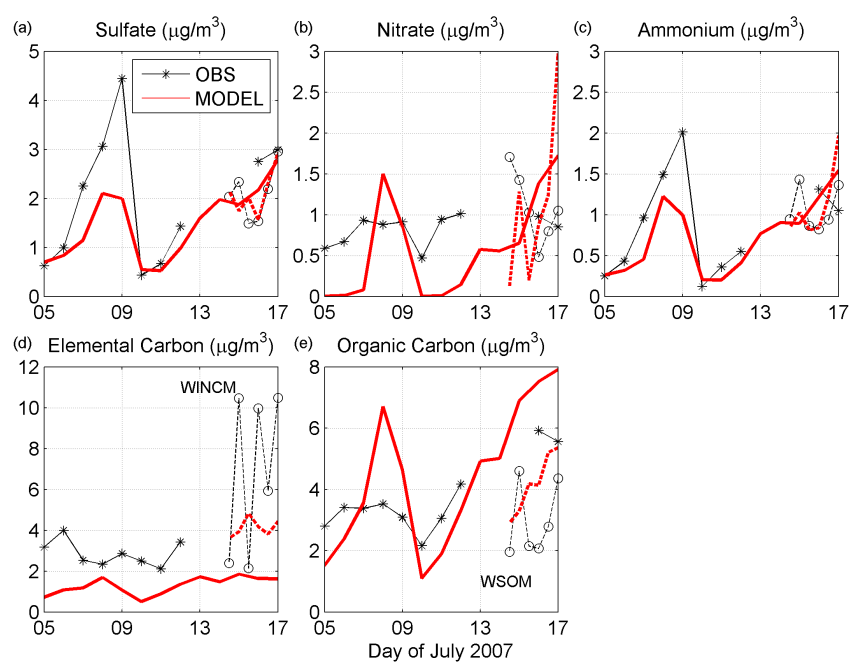

Figure 5. Same as Fig. 2, for daily (solid lines) and twice-daily (dashed lines) particulate-matter composition at ground level in Milan on 5-17 July 2007. Twice-daily observations (dashed lines) are available only from 14 to 17 July. In panel (d), WINCM is the water-insoluble carbon mass $(\mathrm{EC}+$ mostly primary $\mathrm{OC})$; in panel (e) WSOM is water-soluble organic mass (mostly secondary organic aerosol; Carbone et al., 2010).

cle (maximum at night and minimum during the day) which is not captured by the model. The organic-carbon trend and magnitude are reproduced quite well, with the exception of a large spurious peak on 8-9 July not seen in the observations. The peak is associated with secondary organic aerosol (not shown). The twice-daily observations of soluble organic material (WSOM) do not show the strong daily cycle of primary carbonaceous matter and confirm a tendency of the model to overestimate the SOA fraction.

In Fig. 6 we qualitatively compare the lidar profiles with the simulated $\mathrm{PM}_{2.5}$ profiles. A quantitative comparison would require the calculation of optical properties of simulated $\mathrm{PM}_{2.5}$ and subsequent solution of the lidar equation (Hodzic et al., 2004). However, a first-approximation lidar signal may be associated with $\mathrm{PM}_{2.5}$ mass. The model captures some of the basic features of the previously described aerosol profile cycle observed in this period (Sect. 5.1). Every morning a plume of fresh aerosol detaches from the ground and traces the growing boundary layer until its maximum extension in the central part of the day. Then, in the afternoon, the mountain-valley breeze cleans the lower PBL (note the abrupt abatement of both the lidar and the model aerosol signals in the second part of the day), often leaving an upper-air aerosol residual layer above. Model simulations also reproduce such residual layers (note the afternoon increase of $\mathrm{PM}_{2.5}$ values in the upper levels, particularly visible on 15-16 July). When such residual layers persist overnight, the lidar shows these to entrain into the developing PBL the day after (note the merging of the upper-level aerosol layers with the growing, aerosol-traced PBL in Fig. 6a, particularly
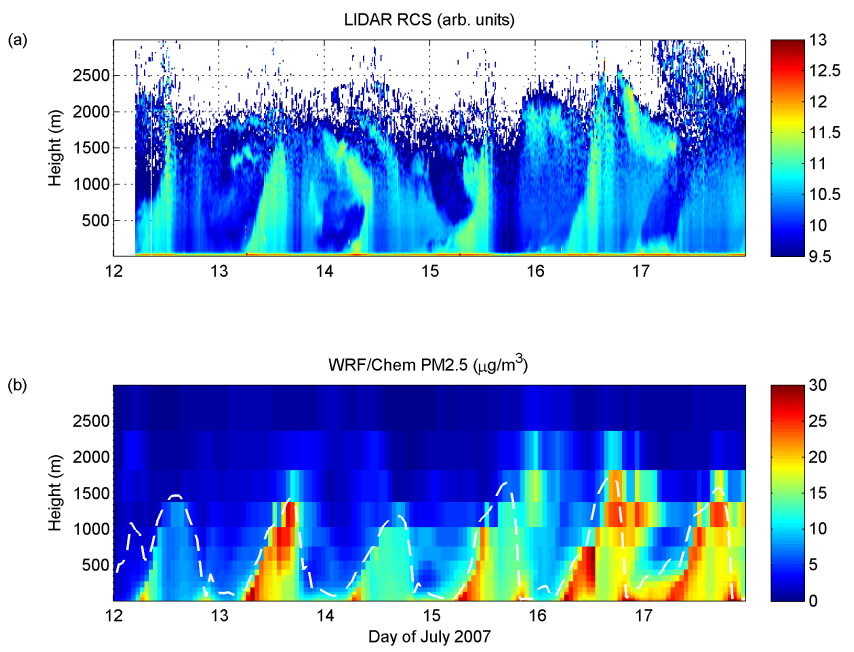

Figure 6. Qualitative comparison of (a) lidar range-corrected signal and (b) simulated $\mathrm{PM}_{2.5}$ vertical profile over Milan on 12-17 July 2007. The white dashed line in the bottom panel denotes the simulated PBL height.

evident in the morning of 14 and 15 July). There are also hints of the same features in model simulations.

\subsection{Insights into the budget of the aerosol vertical profile over Milan}

The "chemical restart" caused by the passage of the perturbation on 9-10 July, and the following settling of an almost periodic circulation pattern, naturally creates favourable conditions for a study of the processes leading to aerosol production and accumulation in the area of Milan. Our analysis shall now focus on the days following the perturbation (1217 July).

Using model output, we firstly examined the composition of the aerosol layers noted in the lidar profiles of Fig. 6. In Fig. 7, we show the composition of $\mathrm{PM}_{2.5}$ simulated over Milan. The model predicts a major role played by the primary fraction (unspeciated anthropogenic, black carbon and primary organic carbon), which is largely responsible for the two rush hours peaks (morning and evening) and the bulk of aerosol mass in the PBL. Fresh emissions are mostly concentrated near the ground and turbulent transport dilutes them in the PBL during the day. A relatively small fraction $(\sim 30 \%)$ of primary aerosol remains above the PBL overnight and contributes to the upper aerosol layers seen by the lidar.

The sum of secondary species contributes $40-60 \%$ of the aerosol mass in the PBL but with remarkable differences in the vertical distribution of single components. Sulfate and SOA start to form and dilute under the PBL a few hours after sunrise, contributing in a relatively homogeneous way to the aerosol column in the PBL. Anthropogenic SOA (ASOA) contributes more than biogenic SOA (BSOA) to the SOA budget. The concentration of these secondary species is sim- 


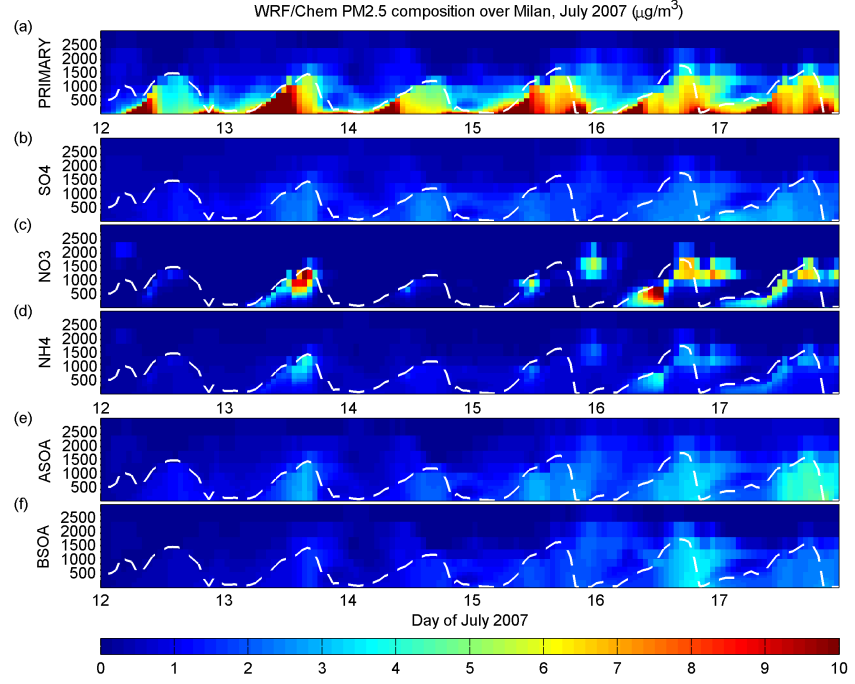

Figure 7. Simulated composition of $\mathrm{PM}_{2.5}$ profile shown in Fig. 6. ASOA and BSOA in panels $(\mathbf{e}, \mathbf{f})$ are anthropogenic and biogenic secondary organic aerosol, respectively.

ilar also above the PBL, thus significantly contributing to the upper aerosol layers. ASOA are slightly more persistent than BSOA and sulfate in the free troposphere.

Nitrate displays a profile substantially different compared to other species, with enhanced concentrations in the upper part of the PBL formed during the central part of the day. These concentrations may largely exceed those found near the ground (i.e. on 13, 16, 17 July). Moreover, nitrate is predicted to be the major secondary species contributing to the formation of the residual aerosol layers above the PBL. Enhanced upper-level concentrations of nitrate into $\mathrm{PM}_{1}$ were also reported at Monte Cimone (a mountain peak of $2160 \mathrm{~m}$ at the southern border of the Po Valley) by Carbone et al. (2010, 2014).

In Fig. 8 we show the maps of simulated sulfate and nitrate over the Po Valley on 13 July 2007 at 16:00 LST at the surface and at $750 \mathrm{~m}$ height. It can be seen that the main features of the composition of the aerosol profile outlined above are not peculiar to the Milan area but appear to be representative of the larger area of the Po Valley.

In order to better understand the processes underlying the predicted characteristics of the aerosol over Milan, we analysed the terms of the continuity equation for chemical species. Budget terms considered are emission, horizontal and vertical advection, chemistry, turbulent mixing, and dry deposition. Terms related to cloud processes (convection, aqueous chemistry, wet deposition) make a very small contribution in the dry period under investigation and are not shown to improve the figure's clarity. In Fig. 9 we show the vertical profile of the budget terms for sulfate and nitrate at 16:00 LST on 13 July over Milan. For sulfate, the dominant terms are those related to advection, indicating the presence of spatially distributed sources and a relatively long life-
Table 2. Description of sensitivity tests with WRF/Chem model.

\begin{tabular}{ll}
\hline Label & Description \\
\hline CTRL & $\begin{array}{l}\text { Reference run, see Table 1 } \\
\text { AERO }\end{array}$ \\
APBL & $\begin{array}{l}\text { Gas and aerosol chemical processes switched } \\
\text { off in the lower half of the PBL } \\
\text { Gas and aerosol chemical processes switched } \\
\text { UPB in the upper half of the PBL }\end{array}$ \\
APBL & $\begin{array}{l}\text { Gas and aerosol chemical processes switched } \\
\text { off above the PBL }\end{array}$ \\
\hline
\end{tabular}

time, making it a regional-scale pollutant. Locally, sulfate is both directly emitted and produced by secondary pathways throughout the PBL. Turbulent mixing distributes it vertically in the PBL and dry deposition removes it from the atmosphere near the ground, determining an almost homogeneous sulfate profile in the PBL. Conversely, nitrate has relatively low contribution from advection, while the largest terms are chemistry and vertical mixing. In the simulation, nitrate is produced only in the upper half of the PBL and destroyed in the lower half. The vertical transition between the nitrate destruction and production zone is quite sharp. Turbulent mixing is nearly in equilibrium with chemical production, indicating that the model simulates a very rapid adjustment to the thermodynamic equilibrium for the sulfatenitrate-ammonium system. This results in nitrate concentrations higher in the upper part of the PBL compared to the lower part.

Similar to nitrate, SOA also displays an enhanced net chemical production in the upper part of the PBL and destruction in the lower part (Fig. 10), but since the chemical and vertical mixing terms are of the same order of the advection terms the resulting vertical profile is almost constant with height, similar to that of sulfate.

Further insights into the simulated sharp transition to an environment favourable to nitrate formation in the upper part of the PBL are investigated by means of several model sensitivity tests as outlined in Table 2. In Fig. 10 we first look at the gas-phase precursor of nitrate, nitric acid $\left(\mathrm{HNO}_{3}\right)$. The left panel shows the vertical profile of the budget terms for $\mathrm{HNO}_{3}$ at the same point as in Fig. 9. The chemical and vertical mixing terms mirror those of particulate nitrate, resulting in a decreasing concentration profile with height. The right panel of Fig. 9 shows the budget profile from a sensitivity simulation where aerosol chemistry is switched off (AERO, see Table 2). The chemistry and vertical mixing terms are greatly reduced and are the same order of magnitude as advective terms, indicating that the sharp gradients in net chemical production of $\mathrm{HNO}_{3}$ (and nitrate) are dominated by aerosol processes and not by gas-phase processes. 
(a)
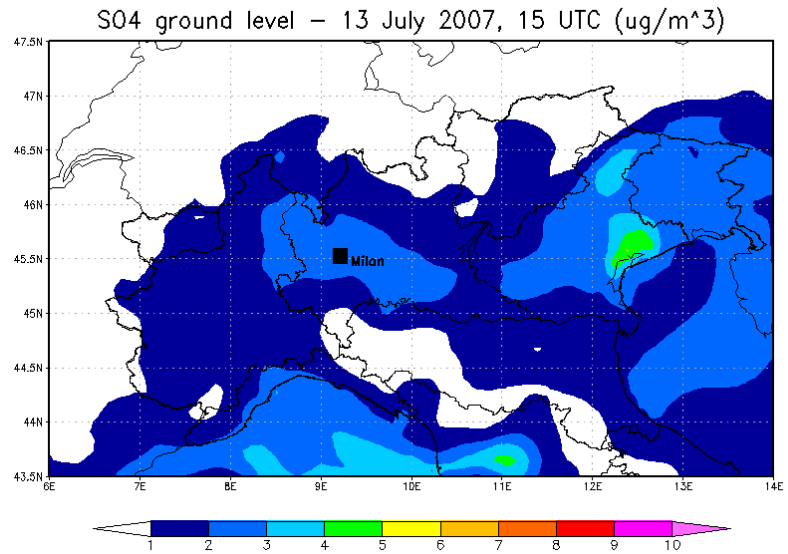

(c)

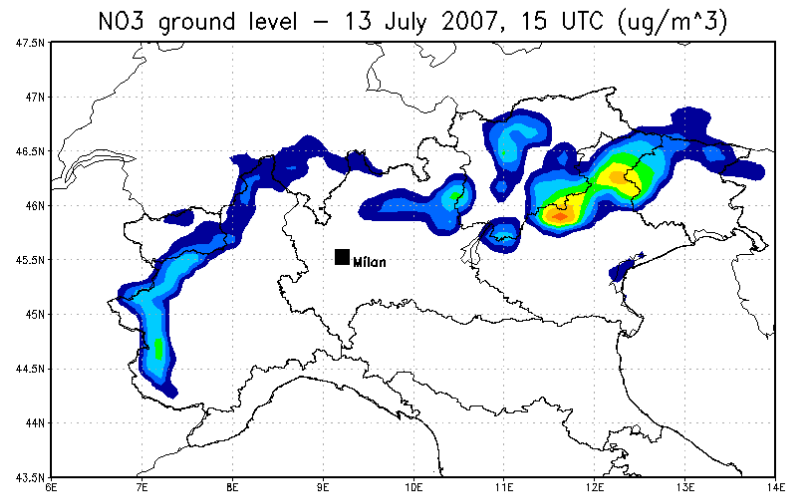

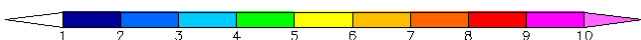

(b)

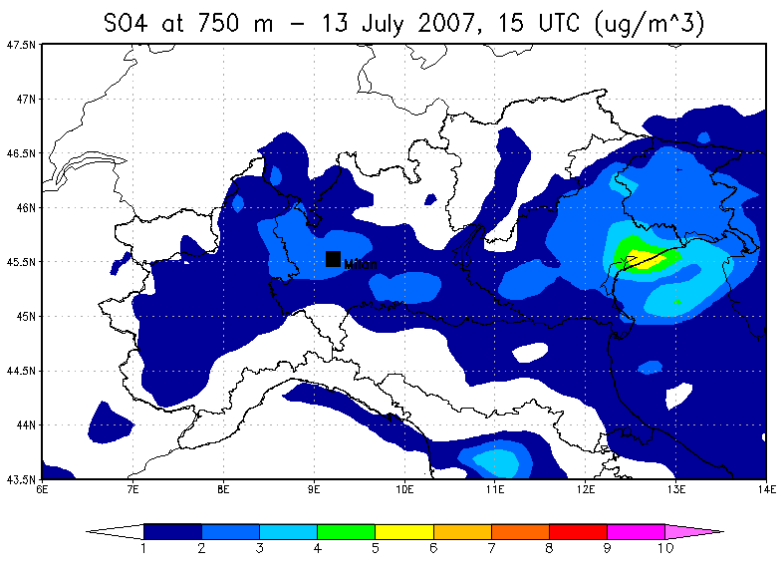

(d)
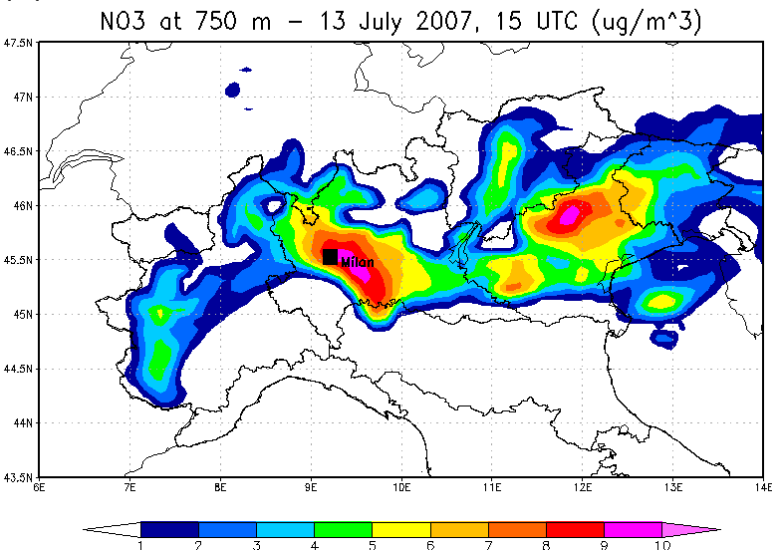

Figure 8. Maps of the concentration of $\mathrm{PM}_{2.5}$ sulfate $(\mathbf{a}, \mathbf{b})$ and nitrate $(\mathbf{c}, \mathbf{d})$ components simulated at 16:00 LST on 13 July 2007 over the Po Valley. Panels (a-c) show ground-level concentrations (the first model level is about $24 \mathrm{~m}$ thick); panels (b-d) show concentrations at approximately $750 \mathrm{~m}$.
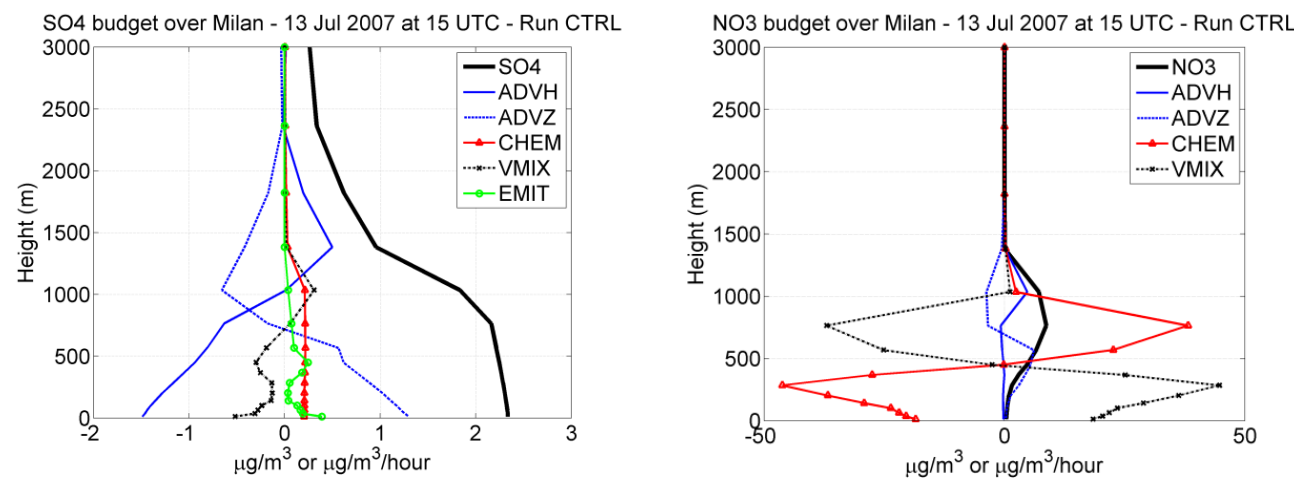

Figure 9. Simulated vertical profile of concentration $\left(\mu \mathrm{g} \mathrm{m}^{-3}\right)$ and continuity equation terms $\left(\mu \mathrm{g} \mathrm{m}^{-3} \mathrm{~h}^{-1}\right.$ ) for particulate sulfate (left) and nitrate (right) at 16:00 LST on 13 July 2007 over Milan. Budget terms are horizontal advection (ADVH), vertical advection (ADVZ), chemistry (CHEM), turbulent mixing and dry deposition (VMIX) and emission (EMIT).

In Fig. 12 we provide further elements to evaluate the simulated particulate-nitrate thermodynamics. Ambient relative humidity increases with height in the PBL, from a minimum of $\sim 50 \%$ near the ground to a maximum of $\sim 80 \%$ at an altitude of $1000 \mathrm{~m}(\sim 400 \mathrm{~m}$ below the PBL top). The nitrate chemical production term shown in Fig. 9 is reported for ease of comparison and displays the peak already noted between 500 and $1000 \mathrm{~m}$. The sulfate ratio (ratio of total ammonia and 


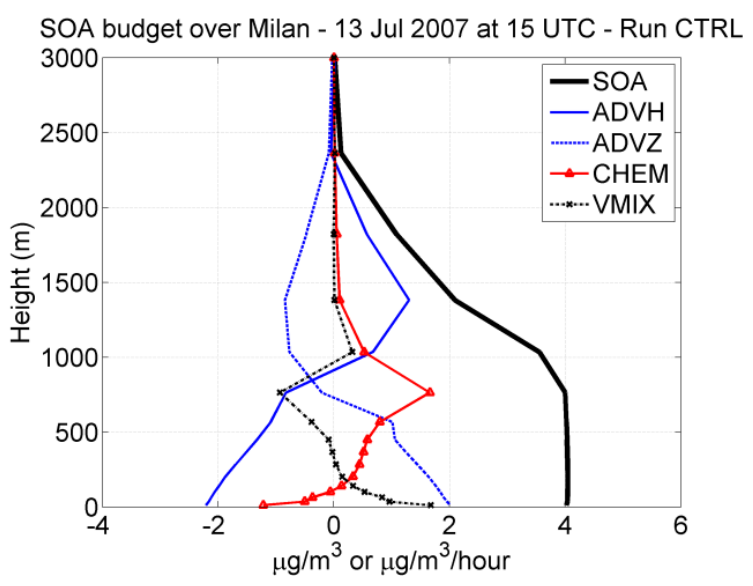

Figure 10. Same as Fig. 9 but for secondary organic aerosol (SOA).

sulfate) is well above the threshold of 2 along the profiles (not shown) and is thus suitable for particulate-nitrate formation (Seinfeld and Pandis, 2006). The profile of equilibrium constants for both the aqueous and solid nitrate increases with height, in response to a decreasing temperature profile (not shown), indicating that the conversion of nitric acid to particulate is favoured with increasing height. However, no sharp transitions, correlated to the nitrate net chemical term, can be noticed in the profiles of these equilibrium constants.

The profile of ammonium nitrate's deliquescence relative humidity (DRH) helps disclose the possible reason for such a transition. At ground level, ambient RH is well below the ammonium nitrate DRH, indicating an environment thermodynamically favourable only to the solid form of nitrate. However, since the RH gradient with height is steeper than that of DRH, the two curves intersect at an altitude of $\sim 500 \mathrm{~m}$, and then again at $\sim 1300 \mathrm{~m}$, because of the RH decrease near the PBL top. Ambient RH is thus higher than ammonium nitrate DRH in the same altitude range $(\sim 500-1000 \mathrm{~m})$ in which the nitrate net chemical production peaks. This indicates that, over Milan and in the period under consideration, the nitrate chemical production is dominated by aqueous conversion of nitric acid to nitrate ion, a condition that is reached only in the upper part of the PBL, where RH levels are high enough to sustain the formation of an aqueous solution containing nitrate. Although the real multicomponent DRH point will differ from that of pure nitrate, it is known that the DRH of mixtures is always lower than that of pure salts (Seinfeld and Pandis, 2006). The thickness of the layer favourable to aqueous-nitrate formation deducible from Fig. 12 may thus be regarded as a conservative lower estimate. During daytime, the nitrate formed in the upper boundary layer re-evaporates back to the gas phase when brought to the ground by vertical motions, and this is the origin of the inhomogeneous vertical profile of nitrate. For further discussion on how much the upper aerosol layer contributes to ground PM, we point the reader to the next paragraph.
The budget analysis we have presented so far reveals a complex interplay between chemical processes and vertical mixing taking place at different altitude ranges. In order to better quantify the impact of chemical production at upper layers on particulate matter at ground level, we perform three tests, alternatively switching the chemical process on and off at selected altitude ranges (namely within the lower half of the PBL; the upper half of the PBL and above the PBL, see Table 2). Results are shown in Fig. 13 for $\mathrm{PM}_{2.5}$ and its components sulfate, nitrate and SOA. In the figure, the contribution to the ground $\mathrm{PM}_{2.5}$ of the chemical processes in the different altitude ranges is positive/negative when the associated sensitivity line is below/above the CTRL. For $\mathrm{PM}_{2.5}$, we have found that chemical process in all regions positively contribute to the ground-level concentration. During the first days after the passage of the perturbation, the shutdown of secondary chemical formation makes very little difference, indicating a dominance of primary emissions. As time goes by, secondary processes gain importance, but primary fraction remains the main driver of $\mathrm{PM}_{2.5}$ concentration even after 1 week. Interestingly, the magnitude of the relative contribution of the different layers (lower PBL, upper PBL, above $\mathrm{PBL}$ ) to ground-level $\mathrm{PM}_{2.5}$ is comparable, and of the order of up to $7-8 \mu \mathrm{g} \mathrm{m}^{-3}$ each, on an hourly basis. Exceptions are noted on the afternoons of 13 and 16 July, when a negative contribution from secondary processes in the lower PBL is simulated (note the blue dashed line above the red line). These peaks are associated with the nitrate sink in the lower PBL (see panel c). Sulfate has an identical contribution from lower- and upper-PBL chemical production and may also have a very important contribution from the region above the PBL, even higher than processes in the PBL (e.g. on 17 July). SOA budget is similar to that of sulfate but with an enhanced contribution from PBL processes vs. those above it. As expected, nitrate displays distinctive features. Chemical production in the lower PBL contributes positively to ground-level concentration in the first part of the day and, then, in the afternoon results in a net destruction. On the other hand, processes in the upper PBL and above the PBL always contribute positively to ground-level nitrate concentrations.

A further quantitative assessment of the impact of upper aerosol layers on ground concentrations can be estimated combining information in Figs. 14 and 6. In Fig. 14 we show the time series of the difference in the simulated $\mathrm{PM}_{2.5}$ profile between APBL and CTRL runs. When a residual layer is visible, we may roughly estimate from the figure the related change near the surface on the subsequent morning. We focus our attention on 17 July, when the presence of a residual layer is clearly visible. The concentration change (APBL-CTRL) in the residual layer is about $8-10 \mu \mathrm{g} \mathrm{m}^{-3}$. The following morning the concentration change near the surface is $4-5 \mu \mathrm{g} \mathrm{m}^{-3}$; thus, we may estimate a $50 \%$ sensitivity of ground $\mathrm{PM}_{2.5}$ to a change in the residual layer. In Fig. 6b, we see that on 17 July the $\mathrm{PM}_{2.5}$ concentration in the residual layer is $20-24 \mu \mathrm{g} \mathrm{m}^{-3}$; thus, the expected impact on 

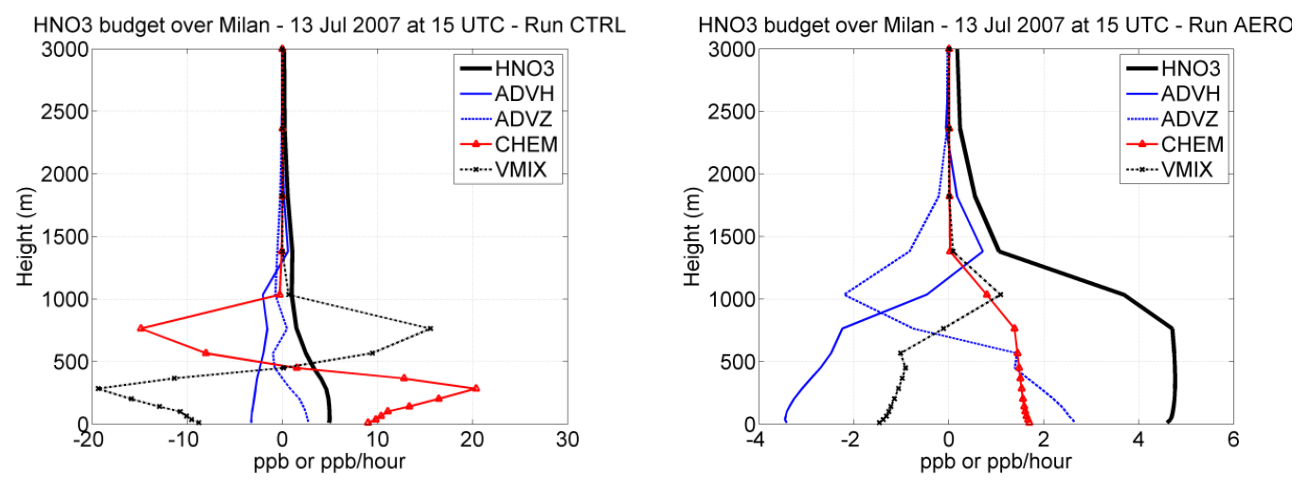

Figure 11. Same as Fig. 9 but for nitric acid $\left(\mathrm{HNO}_{3}\right)$ and units in ppb: on the left the reference simulation (CTRL); on the right a sensitivity simulation with aerosol chemistry switched off (AERO). Please note the different abscissa ranges.

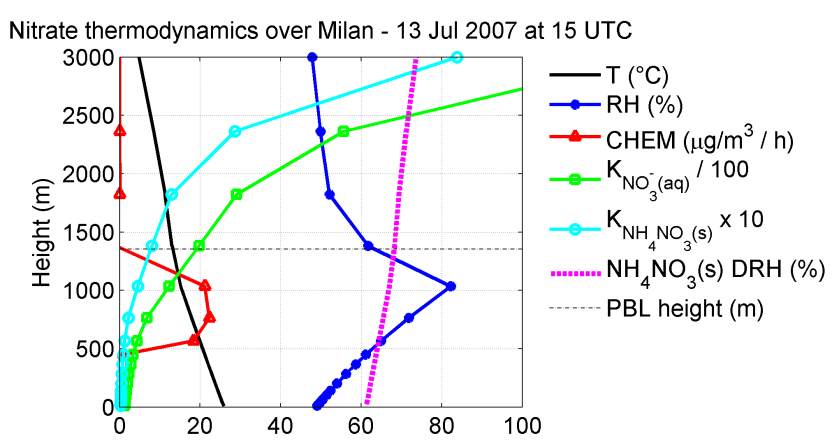

Figure 12. Simulated vertical profile of relative humidity (blue) and particulate-nitrate net chemical production term (red) at 16:00 LST on 13 July 2007 over Milan. Also shown are the vertical profiles of equilibrium constants of aqueous-phase nitrate (green) and solid ammonium nitrate (cyan), and ammonium nitrate deliquescence relative humidity (magenta). The height of PBL is denoted by the horizontal black dashed line. Please note that equilibrium constants are scaled by the constant factors shown in the inset legend to fit on the same abscissa range.

hourly concentrations near the ground is of the order of 10 $12 \mu \mathrm{g} \mathrm{m}^{-3}$, or about $40 \%$ of the $\mathrm{PM}_{2.5}$ concentration near the ground. This is the extreme case in the short period analysed here, but it gives a sense of the potential importance that entrainment of aerosol layers aloft may occasionally have for $\mathrm{PM}_{2.5}$ observed near the surface.

\section{Conclusions}

The object of this study is the analysis of the role played by the combination of chemical and dynamical processes occurring throughout and above the PBL in determining the aerosol concentration and composition we observe near the ground. We analysed the observations of the atmospheric composition carried out over a period of 2 weeks in Milan (northern Italy) in July 2007. The period was characterized by the passage of a perturbation that favoured cleansing of

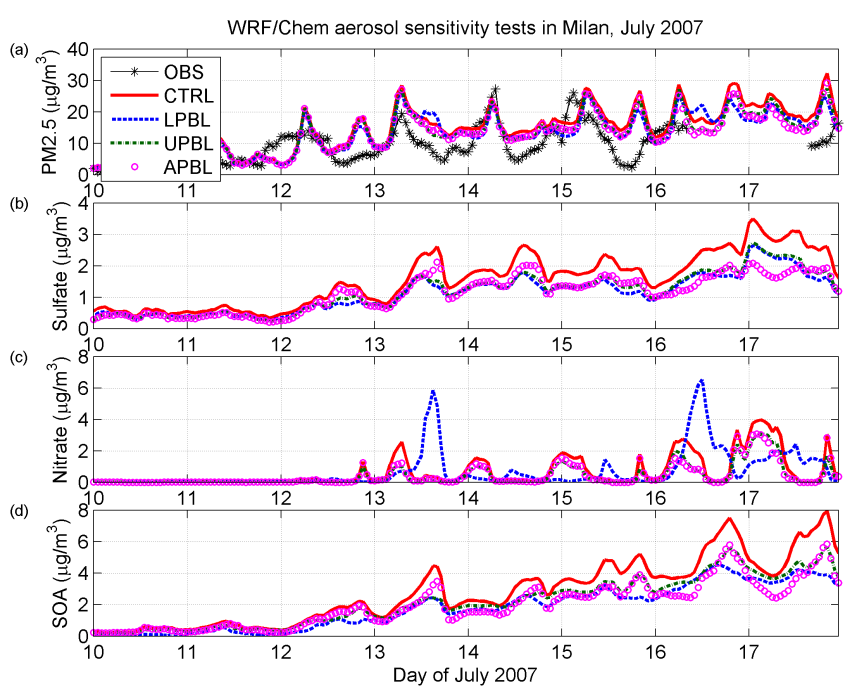

Figure 13. Sensitivity tests on chemical production in different vertical layers (see Table 2 for explanation of labels) at ground level over Milan on 10-17 July 2007. Hourly observations (black line) are only available for $\mathrm{PM}_{2.5}$ (top panel).

the air in the Po Valley, providing a natural chemical restart. After the perturbation, stable high-pressure conditions determined the establishment of a nearly repetitive meteorological pattern, driven by a mountain-valley breeze system that allowed for a gradual re-accumulation of pollutants.

Lidar observations after the chemical restart revealed intriguing features of the aerosol vertical profile over Milan. Every morning, a plume of fresh emissions from the ground is dispersed in the growing convective boundary layer. In the afternoon, an enhanced aerosol layer appears in the upper part of the PBL, while in the evening the bottom part of the PBL is cleansed by the mountain breeze. A residual aerosol layer may form and survive the night above the PBL and may be entrained down to the ground again the day after. We investigated how this "vertical" sequence of processes affect the aerosol concentrations observed at ground level. 


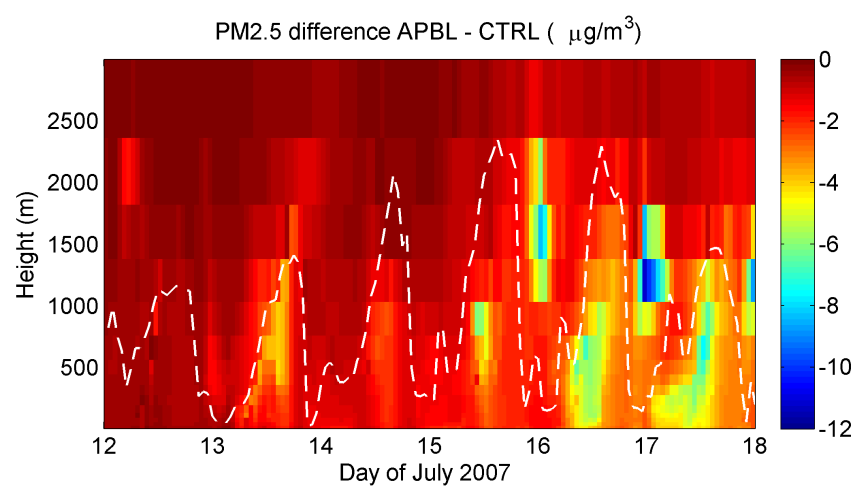

Figure 14. Difference in the simulated $\mathrm{PM}_{2.5}$ profile over Milan between APBL and CTRL runs (see Table 2). In combination with Fig. 6b, this is useful for estimating the impact of the aerosol residual layer on ground concentrations.

With the help of simulations from the state-of-art online meteorology-chemistry model WRF/Chem we attempted to answer three main questions resulting from the observations. The questions and the relevant answers are summarized below:

- What is the composition of the aerosol layer formed during the day in the upper PBL?

Model simulations suggest that $40-60 \%$ of the fine aerosol in Milan's summer PBL is of primary origin, consistent with previous studies (e.g. Carbone et al., 2010). This primary fraction displays a decreasing concentration profile with height in the PBL, since the sources are concentrated near the ground and species are vertically mixed by turbulence. Sulfate and secondary organic aerosol are produced throughout the PBL and have a nearly homogeneous profile there. Nitrate and ammonium have a distinct profile, with enhanced values in the upper PBL, where concentrations may be much higher than near the ground. The low temperature and the relative humidity above the ammonium nitrate deliquescence point in the upper PBL are thought to determine this peculiar profile. Nitrate is the major component of the upper-PBL aerosol layer, contributing up to $30 \%$ of the aerosol mass.

- How much of the aerosol burden measured on the ground is due to localized processes and, conversely, how much is due to processes occurring in the upper PBL and to the subsequent mixing in the lowermost levels? In other words, how important is the interplay between surface and upper layers in shaping the aerosol mass we measure near the ground?
For $\mathrm{PM}_{2.5}$ mass, our calculations indicate that, in the upper PBL, secondary aerosols are formed and then mixed in the PBL by turbulence. The importance of the secondary fraction increases with the aging of air masses, as shown by the progression of days from the chemical restart. One week after the perturbation, secondary $\mathrm{PM}_{2.5}$ produced in the upper PBL may contribute up to $7-8 \mu \mathrm{g} \mathrm{m}^{-3}$ (or $25 \%$ ) to ground-level hourly concentrations. Sulfate and SOA production is equally shared by the bottom and upper PBL, while nitrate is mostly produced in the upper PBL, with the bottom PBL acting as a sink during the afternoon.

- How much may the residual layer above the PBL contribute to the aerosol budget at ground level the next day?

It is calculated that the chemical production above the PBL significantly impacts aerosol levels near the ground, sometimes overtaking the contribution from the production term in the PBL (especially for sulfate and SOA). We estimate that the residual layer above the PBL, which is formed by both primary and secondary species, may occasionally contribute up to 10 $12 \mu \mathrm{g} \mathrm{m}^{-3}$ (or $40 \%$ ) to ground-level $\mathrm{PM}_{2.5}$ hourly concentrations during the following morning.

The peculiar features of the vertical profile of aerosol nitrate have already emerged in past studies. Neuman et al. (2003) reported aircraft observations of increasing nitrate profiles with height, attributing them to the favourable lower temperature in the upper layers, compared to the bottom PBL, due to the conversion of nitric acid to aerosol nitrate. We confirm their conclusion and add that a key role in shaping the aerosol nitrate production profile is played by the relative humidity. In particular, nitrate production may be enhanced when RH is above the ammonium nitrate deliquescence point.

This study has focused on some less obvious and recognized aspects of the aerosol vertical profile budget. Since it is based on the analysis of a short period of high-pressure conditions in summer over the area of Milan, further analyses are recommended for winter periods and different meteorological and geographical conditions. Moreover, it clearly underlines the fact that the interplay between chemical and dynamical processes must be considered when interpreting atmospheric chemistry observations near the ground and that more observational constraints (e.g. profiles of the aerosol composition in and above the PBL) would certainly be helpful to achieve a better simulation of these processes. 
Appendix A: Definition of statistical indices used in model-to-observations comparison

Let $\mathrm{Obs}_{i}$ and $\operatorname{Mod}_{i}$ be the observed and modelled values at time $i$, and $N$ the number of observations.

- The Pearson's correlation $(r)$ :

$$
\begin{gathered}
r=\frac{1}{N} \sum_{i=1}^{N} Z_{i}(\mathrm{Mod}) \times Z_{i}(\mathrm{Obs}) \\
Z(\boldsymbol{X})=\frac{\boldsymbol{X}-\langle\boldsymbol{X}\rangle}{\sigma_{X}},
\end{gathered}
$$

where $\boldsymbol{X}$ is a generic vector, $Z(\boldsymbol{X})$ is its standard score and $\sigma_{X}$ is the standard deviation.

- Bias:

$$
\text { Bias }=\frac{1}{N}\left(\sum_{i=1}^{N} \operatorname{Mod}_{i}-\operatorname{Obs}_{i}\right) .
$$

- Normalized mean bias (NMB):

$$
\mathrm{NMB}=\frac{1}{N} \sum_{i=1}^{N} \frac{\operatorname{Mod}_{i}-\mathrm{Obs}_{i}}{\mathrm{Obs}_{i}} \times 100 .
$$

- Root mean square error (RMSE):

$$
\mathrm{RMSE}=\sqrt{\frac{1}{N}\left(\sum_{i=1}^{N}\left(\operatorname{Mod}_{i}-\mathrm{Obs}_{i}\right)^{2}\right)}
$$




\section{The Supplement related to this article is available online at doi:10.5194/acp-15-2629-2015-supplement.}

Acknowledgements. This work was partly funded by the Italian Space Agency (ASI) within the QUITSAT (contract I/035/06/0) project. G. Curci and P. Tuccella are supported by ASI in the context of the PRIMES project (contract I/017/11/0). The authors are extremely thankful to the Euro-Mediterranean Centre on Climate Change (CMCC) for having made available the computational resources needed to complete this work. Meteorological and gas-phase observations near the ground are taken from the weather station operated in Milan by the regional environmental agency (ARPA Lombardia). The authors gratefully acknowledge the Wetterzentrale, the NOAA Air Resources Laboratory (ARL), the AERONET network, the MODIS Rapid Response System and the Barcelona Supercomputing Center for the material used in the online supplement to this paper.

Edited by: A. Carlton

\section{References}

Aan de Brugh, J. M. J., Schaap, M., Vignati, E., Dentener, F., Kahnert, M., Sofiev, M., Huijnen, V., and Krol, M. C.: The European aerosol budget in 2006, Atmos. Chem. Phys., 11, 1117-1139, doi:10.5194/acp-11-1117-2011, 2011

Aan de Brugh, J. M. J., Henzing, J. S., Schaap, M., Morgan, W. T., van Heerwaarden, C. C., Weijers, E. P., Coe, H., and Krol, M. C.: Modelling the partitioning of ammonium nitrate in the convective boundary layer, Atmos. Chem. Phys., 12, 3005-3023, doi:10.5194/acp-12-3005-2012, 2012.

Ackermann, I. J., Hass, H., Memmsheimer, M., Ebel, A., Binkowski, F. S., and Shankar, U.: Modal aerosol dynamics model for Europe: developmentand first applications, Atmos. Environ., 32, 2981-2999, doi:10.1016/S1352-2310(98)00006-5, 1998.

Ahmadov, R., McKeen, S. A., Robinson, A. L., Bahreini, R., Middlebrook, A. M., de Gouw, J. A., Meagher, J., Hsie, E.Y., Edgerton, E., Shaw, S., and Trainer, M.: A volatile basis set model for summertime secondary organic aerosols over the eastern United States in 2006, J. Geophys. Res., 117, D06301, doi:10.1029/2011JD016831, 2012.

Alapaty, K. V., Mathur, R., Pleim, J. E., Hogrefe, C., Rao, S. T., Ramaswamy, V., Galmarini, S., Schapp, M., Vautard, R., Makar, R., Baklanov, A., Kallos, G.,Vogel, B., and Sokhi, R.: New Directions: Understanding Interactions of Air Quality and Climate Change at Regional Scales, Atmos. Environ., Elsevier Science Ltd, New York, NY, 49, 1-424, 2012.

Allwine, K. J. and Whiteman, C. D.: Single-station integral measures of atmospheric stagnation, recirculation and ventilation, Atmos. Environ., 28, 713-721, 1994.

Angelini, F., Barnaba, F., Landi, T. C., Caporaso, L., and Gobbi, G. P.: Study of atmospheric aerosols and mixing layer by LIDAR, Radiat. Prot. Dosim., 137, 275-279, 2009.
Baltensperger, U., Streit, N., Weingartner, E., Nyeki, S., Prévot, A. S. H., Van Dingenen, R., Virkkula, A., Putaud, J.-P., Even, A., ten Brink, H., Blatter, A., Neftel, A., and Gaggeler, H. W.: Urban and rural aerosol characterization of summer smog events during the PIPAPO field campaign in Milan, Italy, J. Geophys. Res., 107, 8193, doi:10.1029/2001JD001292, 2002.

Barnaba, F. and Gobbi, G. P.: Aerosol seasonal variability over the Mediterranean region and relative impact of maritime, continental and Saharan dust particles over the basin from MODIS data in the year 2001, Atmos. Chem. Phys., 4, 2367-2391, doi:10.5194/acp-4-2367-2004, 2004.

Barnaba, F., Gobbi, G. P., and de Leeuw, G.: Aerosol stratification, optical properties and radiative forcing in Venice (Italy) during ADRIEX, Q. J. R. Meteorol. Soc., 133, 47-60, 2007.

Barnaba, F., Putaud, J.-P., Gruening, G., dell'Acqua, A., and Dos Santos, S.: Annual cycle in co-located in situ, total-column, and height-resolved observations in the Po Valley (Italy): Implications for ground-level particulate matter mass concentration estimation from remote sensing, J. Geophys. Res., 115, D19209, doi:10.1029/2009JD013002, 2010.

Barnaba, F., Angelini, F., Curci, G., and Gobbi, G. P.: An important fingerprint of wildfires on the European aerosol load, Atmos. Chem. Phys., 11, 10487-10501, doi:10.5194/acp-1110487-2011, 2011.

Barnard, J. C., Fast, J. D., Paredes-Miranda, G., Arnott, W. P., and Laskin, A.: Technical Note: Evaluation of the WRF-Chem "Aerosol Chemical to Aerosol Optical Properties" Module using data from the MILAGRO campaign, Atmos. Chem. Phys., 10, 7325-7340, doi:10.5194/acp-10-7325-2010, 2010.

Beelen, R., Raaschou-Nielsen, O., Stafoggia, M., Andersen, Z. J., Weinmayr, G., Hoffmann, B., Wolf, K., Samoli, E., Fischer, P., Nieuwenhuijsen, M., Vineis, P., Xun, W. W., Katsouyanni, K., Dimakopoulou, K., Oudin, A., Forsberg, B., Modig, L., Havulinna, A. S., Lanki, T., Turunen, A., Oftedal, B., Nystad, W., Nafstad, P., De Faire, U., Pedersen, N. L., Östenson, C.G., Fratiglioni, L., Penell, J., Korek, M., Pershagen, G., Eriksen, K. T., Overvad, K., Ellermann, T., Eeftens, M., Peeters, P. H., Meliefste, K., Wang, M., Bueno-de-Mesquita, B., Sugiri, D., Krämer, U., Heinrich, J., de Hoogh, K., Key, T., Peters, A., Hampel, R., Concin, H., Nagel, G., Ineichen, A., Schaffner, E., ProbstHensch, N., Künzli, N., Schindler, C., Schikowski, T., Adam, M., Phuleria, H., Vilier, A., Clavel-Chapelon, F., Declercq, C., Grioni, S., Krogh, V., Tsai, M.-Y., Ricceri, F., Sacerdote, C., Galassi, C., Migliore, E., Ranzi, A., Cesaroni, G., Badaloni, C., Forastiere, F., Tamayo, I., Amiano, P., Dorronsoro, M., Katsoulis, M., Trichopoulou, A., Brunekreef, B., and Hoek, G.: Effects of long-term exposure to air pollution on natural-cause mortality: an analysis of 22 European cohorts within the multicentre ESCAPE project, The Lancet, 383, 785-795, doi:10.1016/S01406736(13)62158-3, 2014.

Binkowski, F. S. and Roselle, S. J.: Models-3 Community Multiscale Air Quality (CMAQ) model aerosol component, 1, Model description, J. Geophys. Res., 108, 4183 , doi:10.1029/2001JD001409, 2003.

Boselli, A., Armenante, M., D’Avino, L., D’Isidoro, M., Pisani, G., Spinelli, N., and Wang, X.: Atmospheric aerosol characterization over Naples during 2000-2003 EARLINET project: Planetary boundary-layer evolution and layering, Boundary-Layer Meteorol., 132, 151-165, doi:10.1007/s10546-009-9382-6, 2009. 
Carbone, C., Decesari, S., Mircea, M., Giulianelli, L., Finessi, E., Rinaldi, M., Fuzzi, S., Marinoni, A., Duchi, R., Perrino, C., Sargolini, T., Vardè, M., Sprovieri, F., Gobbi, G. P., Angelini, F., and Facchini, M. C.: Size-resolved aerosol chemical composition over the Italian Peninsula during typical summer and winter conditions, Atmos. Environ., 44, 5269-5278, 2010.

Carbone, C., Decesari, S., Paglione, M., Giulianelli, L., Rinaldi, M., Marinoni, A., Cristofanelli, P., Didiodato, A., Bonasini, P., Fuzzi, S., and Facchini, M. C.: 3-year chemical composition of free tropospheric $\mathrm{PM}_{1}$ at the Mt. Cimone GAW global station e South Europe e 2165 m a.s.1., Atmos. Environ., 87, 218-227, 2014.

Carnevale, C., Decanini, E., and Volta, M.: Design and validation of a multiphase 3-D model to simulate tropospheric pollution, Sci. Total Environ., 390, 166-176, 2008.

Chen, F. and Dudhia, J.:, Coupling an advanced landsurface/hydrology model with the Penn State/NCAR MM5 modeling system, Part I: Model description and implementation, Mon. Weather Rev., 129, 569-585, doi:10.1175/15200493(2001)129<0569:CAALSH>2.0.CO;2, 2001.

Chu, D. A., Kaufman, Y. J., Zibordi, G., Chern, J. D., Mao, J., Li., C., and Holben, B. N.: Global monitoring of air pollution over land from the Earth Observing System-Terra Moderate Resolution Imaging Spectroradiometer (MODIS), J. Geophys. Res., 108, 4661, doi:10.1029/2002JD003179, 2003.

Clapp, L. J. and Jenkin, M. E.: Analysis of the relationship between ambient levels of $\mathrm{O}_{3}, \mathrm{NO}_{2}$ and $\mathrm{NO}$ as a function of $\mathrm{NO}_{\mathrm{x}}$ in the UK, Atmos. Environ., 35, 6391-6405, 2001.

Cook, J., Highwood, E. J., Coe, H., Formenti, P., Haywood, J. M., and Crosier, J.: A comparison of aerosol optical and chemical properties over the Adriatic and Black Seas during summer 2004: Two case-studies from ADRIEX, Q. J. R. Meteorol. Soc., 133, 33-45, 2007.

Crosier, J., Allan, J. D., Coe, H., Bower, K. N., Formenti, P., and Williams, P. I.: Chemical composition of summertime aerosol in the Po Valley (Italy), northern Adriatic and Black Sea, Q. J. R. Meteorol. Soc., 133, 61-75, 2007.

Daher, N., Ruprecht, A., Invernizzi, G., De Marco, C., MillerSchulze, J., Heo, J. B., Shafer, M. M., Shelton, B. R., Schauer, J. J., and Sioutas, C.: Characterization, sources and redox activity of fine and coarse particulate matter in Milan, Italy, Atmos. Environ., 49, 130-141, 2012.

Decesari, S., Allan, J., Plass-Duelmer, C., Williams, B. J., Paglione, M., Facchini, M. C., O’Dowd, C., Harrison, R. M., Gietl, J. K., Coe, H., Giulianelli, L., Gobbi, G. P., Lanconelli, C., Carbone, C., Worsnop, D., Lambe, A. T., Ahern, A. T., Moretti, F., Tagliavini, E., Elste, T., Gilge, S., Zhang, Y., and Dall'Osto, M.: Measurements of the aerosol chemical composition and mixing state in the Po Valley using multiple spectroscopic techniques, Atmos. Chem. Phys., 14, 12109-12132, doi:10.5194/acp-1412109-2014, 2014

de Meij, A., Wagner, S., Cuvelier, C., Dentener, F., Gobron, N., Thunis, P., and Shaap, M.: Model evaluation and scale issues in chemical and optical aerosol properties over the greater Milan area (Italy), for June 2001, Atmos. Res., 85, 243-267, 2007.

Di Carlo, P., Pitari, G., Mancini, E., Gentile, S., Pichelli, E., and Visconti, G.: Evolution of surface ozone in central Italy based on observations and statistical model, J. Geophys. Res., 112, D10316, doi:10.1029/2006JD007900, 2007.
Di Giuseppe, F., Riccio, A., Caporaso, L., Bonafe, G., Gobbi, G. P., and Angelini, F.: Automatic detection of atmospheric boundary layer height using ceilometer backscatter data assisted by a boundary layer model, Q. J. R. Meteorol. Soc., 138, 649-663, doi:10.1002/qj.964, 2012.

Dosio, A., Galmarini, S., and Graziani, G.: Simulation of the circulation and related photochemical ozone dispersion in the Po plains (northern Italy): Comparison with the observation of a measuring campaign, J. Geophys. Res., 107, 8189, doi:10.1029/2000JD000046, 2002.

Duong, H. T., Sorooshian, A., Craven, J. S., Hersey, S. P., Metcalf, A. R., Zhang, X., Weber, R. J., Jonsson, H., Flagan, R. C., and Seinfeld, J. H.: Water-soluble organic aerosol in the Los Angeles Basin and outflow regions: Airborne and ground measurements during the 2010 CalNex field campaign, J. Geophys. Res., 116, D00V04, doi:10.1029/2011JD016674, 2011.

EC: Directive 2008/50/EC of the European Parliament and of the Council of 21 May 2008 on Ambient Air Quality and Cleaner Air for Europe, 2008.

Estellés, V., Martìnez-Lozano, J. A., Pey, J., Sicard, M., Querol, X., Esteve, A. R., Utrillas, M. P., Sorribas, M., Gangoiti, G., Alastuey, A., and Rocadenbosch, F.: Study of the correlation between columnar aerosol burden, suspended matter at ground and chemical components in a background European environment, J. Geophys. Res., 117, D04201, doi:10.1029/2011JD016356, 2012.

Ferrero, L., Perrone, M. G., Petraccone, S., Sangiorgi, G., Ferrini, B. S., Lo Porto, C., Lazzati, Z., Cocchi, D., Bruno, F., Greco, F., Riccio, A., and Bolzacchini, E.: Vertically-resolved particle size distribution within and above the mixing layer over the Milan metropolitan area, Atmos. Chem. Phys., 10, 3915-3932, doi:10.5194/acp-10-3915-2010, 2010.

Ferrero, L., Riccio, A., Perrone, M. G., Sangiorgi, G., Ferrini, B. S., and Bolzacchini, E.: Mixing height determination by tethered balloon-based particle soundings and modelling simulations, Atmos. Res., 102, 145-156, 2011.

Ferrero, L., Cappelletti, D., Moroni, B., Sangiorgi, G., Perrone, M. G., Crocchianti, S., and Bolzacchini, E.: Wintertime aerosol dynamics and chemical composition across the mixing layer over basin valleys, Atmos. Environ., 56, 143-153, 2012.

Ferrero, L., Castelli, M., Ferrini, B. S., Moscatelli, M., Perrone, M. G., Sangiorgi, G., Rovelli, G., D’Angelo, L., Moroni, B., Scardazza, F., Mocnik, G., Bolzacchini, E., Petitta, M., and Cappelletti, D.: Impact of black carbon aerosol over Italian basin valleys: high resolution measurements along vertical profiles, radiative forcing and heating rate, Atmos. Chem. Phys. Discuss., 14, 541-591, doi:10.5194/acpd-14-541-2014, 2014.

Grell, G. A. and Devenyi, D.: A generalized approach to parameterizing convection combining ensemble and data assimilation techniques, Geophys. Res. Lett., 29, 38-1-38-4 doi:10.1029/2002GL015311, 2002.

Grell, G. A., Peckham, S. E., McKeen, S., Schmitz, R., Frost, G., Skamarock, W. C., and Eder, B.: Fully coupled "online" chemistry within the WRF model, Atmosph. Env., 39, 6957-6975, 2005.

Guenther, A., Karl, T., Harley, P., Wiedinmyer, C., Palmer, P. I., and Geron, C.: Estimates of global terrestrial isoprene emissions using MEGAN (Model of Emissions of Gases and Aerosols from Nature), Atmos. Chem. Phys., 6, 3181-3210, doi:10.5194/acp-63181-2006, 2006. 
Haeffelin M., Angelini, F., Morille, Y., Martucci, G., Frey, S., Gobbi, G. P., Lolli, S., O’Dowd, C. D., Sauvage, L., XuerefRémy, I., Wastine, B., and Feist, D. G.: Evaluation of mixingheight retrievals from automatic profiling lidars and ceilometers in view of future integrated networks in Europe, Bound. Lay. Meteorol., 143, 49-75, 2012.

Hamed, A., Joutsensaari, J., Mikkonen, S., Sogacheva, L., Dal Maso, M., Kulmala, M., Cavalli, F., Fuzzi, S., Facchini, M. C., Decesari, S., Mircea, M., Lehtinen, K. E. J., and Laaksonen, A.: Nucleation and growth of new particles in Po Valley, Italy, Atmos. Chem. Phys., 7, 355-376, doi:10.5194/acp-7-355-2007, 2007.

Harrison, R. M. and Yin, J.: Particulate matter in the atmosphere: which particle properties are important for its effects on health?, Sci. Total Environ., 249, 85-101, 2000.

He, T.-Y., Stanič, S., Gao, F., Bergant, K., Veberič, D., Song, X.Q., and Dolžan, A.: Tracking of urban aerosols using combined LIDAR-based remote sensing and ground-based measurements, Atmos. Meas. Tech., 5, 891-900, doi:10.5194/amt-5-891-2012, 2012.

Heald, C. L., Jacob, D. J., Turquety, S., Hudman, R. C., Weber, R. J., Sullivan, A. P., Peltier, R. E., Atlas, E. L., de Gouw, J. A., Warneke, C., Holloway, J. S., Neuman, J. A., Flocke, F. M., and Seinfeld, J. H.: Concentrations and sources of organic carbon aerosols in the free troposphere over North America, J. Geophys. Res., 111, D23S47, doi:10.1029/2006JD007705, 2006.

Highwood, E. J., Haywood, J. M., Coe, H., Cook, J., Osborne, S., Williams, P., Crosier, J., Bower, K., Formenti, P., McQuaid, J., Brooks, B., Thomas, G., Grainger, R., Barnaba, F., Gobbi, G. P., de Leeuw, G., and Hopkins, J.: Aerosol Direct Radiative Impact Experiment (ADRIEX): overview, Q. J. R. Meteorol. Soc., 133, 3-15, 2007.

Hodzic, A., Chepfer, H., Vautard, R., Chazette, P., Beekmann, M., Bessagnet, B., Chatenet, B., Cuesta, J., Drobinski, P., Goloub, P., Haeffelin, M., and Morille, Y.: Comparison of aerosol chemistry transport model simulations with lidar and Sun photometer observations at a site near Paris, J. Geophys. Res., 109, D23201, doi:10.1029/2004JD004735, 2004.

Hodzic, A., Bessagnet, B., and Vautard, R.: A model evaluation of coarse-mode nitrate heterogeneous formation on dust particles, Atmos. Environ., 40, 4158-4171, 2006.

Hodzic, A., Jimenez, J. L., Madronich, S., Aiken, A. C., Bessagnet, B., Curci, G., Fast, J., Lamarque, J.-F., Onasch, T. B., Roux, G., Schauer, J. J., Stone, E. A., and Ulbrich, I. M.: Modeling organic aerosols during MILAGRO: importance of biogenic secondary organic aerosols, Atmos. Chem. Phys., 9, 6949-6981, doi:10.5194/acp-9-6949-2009, 2009.

Iacono, M. J., Delamere, J. S. , Mlawer, E. J., Shephard, M. W., Clough, S. A., and Collins, W. D.: Radiative forcing by long-lived greenhouse gases: Calculations with the AER radiative transfer models, J. Geophys. Res., 113, D13103, doi:10.1029/2008JD009944, 2008.

Im, U., Bianconi, R., Solazzo, E., Kioutsioukis, I., Badia, A., Balzarini, A., Baro, R., Bellasio, R., Brunner, D., Chemel, C., Curci, G., Flemming, J., Forkel, R., Giordano, L., JimenezGuerrero, P., Hirtl, M., Hodzic, A., Honzak, L., Jorba, O., Knote, C., Kuenen, J. J. P., Makar, P. A., Manders-Groot, A., Neal, L., Perez, J. L., Pirovano, G., Pouliot, G., San Jose, R., Savage, N., Schroder, W., Sokhi, R. S., Syrakov, D., Torian, A., Tuccella, P.,
Werhahn, J., Wolke, R., Yahya, K., Zabkar, R., Zhang, Y., Zhang, J., Hogrefe, C., and Galmarini, S.: Evaluation of operational online-coupled regional air quality models over Europe and North America in the context of AQMEII phase 2. Part I: Ozone, Atmos. Environ., in press, doi:10.1016/j.atmosenv.2014.09.042, 2014a.

Im, U., Bianconi, R., Solazzo, E., Kioutsioukis, I., Badia, A., Balzarini, A., Baro, R., Bellasio, R., Brunner, D., Chemel, C., Curci, G., Denier van der Gon, H., Flemming, J., Forkel, R., Giordano, L., Jimenez-Guerrero, P., Hirtl, M., Hodzic, A., Honzak, L., Jorba, O., Knote, C., Makar, P. A., Manders-Groot, A., Neal, L., Perez, J. L., Pirovano, G., Pouliot, G., San Jose, R., Savage, N., Schroder, W., Sokhi, R. S., Syrakov, D., Torian, A., Tuccella, P., Wang, K., Werhahn, J., Wolke, R., Zabkar, R., Zhang, Y., Zhang, J., Hogrefe, C., and Galmarini, S.: Evaluation of operational online-coupled regional air quality models over Europe and North America in the context of AQMEII phase 2. Part II: Particulate Matter, Atmos. Environ., in press, doi:10.1016/j.atmosenv.2014.08.072, 2014b.

Jenkin, M. E. and Clemitshaw, K. C.: Ozone and other photochemical pollutants: chemical processes governing their formation in the planetary boundary layer, Atmos. Environ., 34, 2499-2527, 2000.

Johnson, B. T., Shine, K. P., and Forster, P. M.: The semi-direct aerosol effect: Impact of absorbing aerosols on marine stratocumulus, Q. J. R. Meteorol. Soc., 130, 1407-1422, 2004.

Kuenen, J. J. P., Visschedijk, A. J. H., Jozwicka, M., and Denier van der Gon, H. A. C.: TNO-MACC_II emission inventory; a multiyear (2003-2009) consistent high-resolution European emission inventory for air quality modelling, Atmos. Chem. Phys., 14, 10963-10976, doi:10.5194/acp-14-10963-2014, 2014.

Lee, T., Yu, X.-Y., Ayres, B., Kreidenweis, S. M., Malm, W. C., and Collet Jr., J. L.: Observations of fine and coarse particle nitrate at several rural locations in the United States, Atmos. Environ., 42, 2720-2732, doi:10.1016/j.atmosenv.2007.05.016, 2008.

Liu, P., Zhang, Y., Yu, S., and Schere, K. L.: Use of a process analysis tool for diagnostic study on fine particulate matter predictions in the U.S. - Part II: Analyses and sensitivity simulations, Atmos. Pol. Res., 2, 61-71, doi:10.5094/APR.2011.008, 2011.

Lohmann, U. and Feichter, J.: Global indirect aerosol effects: a review, Atmos. Chem. Phys., 5, 715-737, doi:10.5194/acp-5-7152005, 2005.

Lonati, G., Giugliano, M., Butelli, P., Romele, L., and Tardivo, R.: Major chemical components of $\mathrm{PM}_{2.5}$ in Milan (Italy), Atmos. Environ., 39, 1925-1934, 2005.

Lonati, G., Crippa, M., Gianelle, V., and Van Dingenen, R.: Daily patterns of the multi-modal structure of the particle number size distribution in Milan, Italy, Atmos. Environ., 45, 2434-2442, 2011.

Maletto, A., McKendry, I. G., and Strawbridge, K. B.: Profiles of particulate matter size distributions using a balloon-borne lightweight aerosol spectrometer in the planetary boundary layer, Atmos. Environ., 37, 661-670, 2003.

Marcazzan, G. M., Vaccaro, S., Valli, G., and Vecchi, R.: Characterization of $\mathrm{PM}_{10}$ and $\mathrm{PM}_{2.5}$ particulate matter in the ambient air of Milan (Italy), Atmos. Environ., 35, 4639-4650, 2001.

Matta, E., Facchini, M. C., Decesari, S., Mircea, M., Cavalli, F., Fuzzi, S., Putaud, J.-P., and Dell'Acqua, A.: Mass closure on the chemical species in size-segregated atmospheric aerosol col- 
lected in an urban area of the Po Valley, Italy, Atmos. Chem. Phys., 3, 623-637, doi:10.5194/acp-3-623-2003, 2003.

Mavroidis, I. and Ilia, M.: Trends of $\mathrm{NO}_{\mathrm{x}}, \mathrm{NO}_{2}$ and $\mathrm{O}_{3}$ concentrations at three different types of air quality monitoring stations in Athens, Greece, Atmos. Environ., 63, 135-147, 2012.

McKeen, S. A., Wotawa, G., Parrish, D. D., Hollaway, J. S., Buhr, M. P., Hubler, G., Fehesenfeld, F. C., and Meagher, J. F.: Ozone production from Canadian wildfires during June and July 1995 , J. Geophys. Res., 107, 4192, doi:10.1029/2001JD000697, 2002.

Misenis, C. and Zhang, Y.: An examination of sensitivity of WRF/Chem predictions to physical parameterizations, horizontal grid spacing, and nesting options, Atmos. Res., 97, 315-334, 2010.

Morgan, W. T., Allan, J. D., Bower, K. N., Capes, G., Crosier, J., Williams, P. I., and Coe, H.: Vertical distribution of sub-micron aerosol chemical composition from North-Western Europe and the North-East Atlantic, Atmos. Chem. Phys., 9, 5389-5401, doi:10.5194/acp-9-5389-2009, 2009.

Morino, Y., Kondo, Y., Takegawa, N., Miyazaki, Y., Kita, K., Komazaki, Y., Fukuda, M., Miyakawa, T., Moteki, N., and Worsnop, D. R.: Partitioning of $\mathrm{HNO}_{3}$ and particulate nitrate over Tokyo: Effect of vertical mixing, J. Geophys. Res., 111, D15215, doi:10.1029/2005JD006887, 2006.

Morrison, H., Thompson, G., and Tatarskii, V.: Impact of cloud microphysics on the development of trailing stratiform precipitation in a simulated squall line: comparison of one- and two-moment scheme, Mon. Weather Rev., 137, 991-1007, doi:10.1175/2008mwr2556.1, 2009.

Nakanishi, M. and Niino, H.: An improved Mellor-Yamada Level-3 Model: Its numerical stability and application to a regional prediction of advection fog, Bound. Lay. Meteorol., 119, 397-407, doi:10.1007/s10546-005-9030-8, 2006.

Neuman, J. A., Nowak, J. B., Brock, C. A., Trainer, M., Fehsenfeld, F. C., Holloway, J. S., Hubler, G., Hudson, P. K., Murphy, D. M., Nicks Jr., D. K., Orsini, D., Parrish, D. D., Ryerson, T. B., Sueper, D. T., Sullivan, A., and Weber, R.: Variability in ammonium nitrate formation and nitric acid depletion with altitude and location over California, J. Geophys. Res., 108, 4557, doi:10.1029/2003JD003616, 2003.

Novakov, T., Hegg. D. A., and Hobbs, P. V.: Airborne measurements of carbonaceous aerosols on the East Coast of the United States, J. Geophys. Res., 102, 30023-30030, doi:10.1029/97JD02793, 1997.

Oberdorster, G.: Pulmonary effects of inhaled ultrafine particles, Int. Arch. Occup. Environ. Health, 74, 1-8, 2001.

O'Dowd, C. D. and Smith, M. H.: The vertical structure of aerosol and its relationship to boundary-layer thermodynamics over the rural UK, Q. J. R. Meteorol. Soc., 122, 1799-1814, 1996.

Ordonez, C., Richter, A., Steinbacher, M., Zellweger, C., Nuss, H., Burrows, J. P., and Prévot, A. S. H.: Comparison of 7 years of satellite-borne and ground-based tropospheric $\mathrm{NO}_{2}$ measurements around Milan, Italy, J. Geophys. Res., 111, D05310, doi:10.1029/2005JD006305, 2006.

Ouwersloot, H. G., Vilà-Guerau de Arellano, J., Nölscher, A. C., Krol, M. C., Ganzeveld, L. N., Breitenberger, C., Mammarella, I., Williams, J., and Lelieveld, J.: Characterization of a boreal convective boundary layer and its impact on atmospheric chemistry during HUMPPA-COPEC-2010, Atmos. Chem. Phys., 12, 9335-9353, doi:10.5194/acp-12-9335-2012, 2012.
Perrone, M. G., Gualtieri, M., Ferrero, L., Lo Porto, C., Udisti, R., Bolzacchini, E., and Camatini, M.: Seasonal variations in chemical composition and in vitro biological effects of fine PM from Milan, Chemosphere, 78, 1368-1377, 2010.

Perrone, M. G., Larsen, B. R., Ferrero, L., Sangiorgi, G., De Gennaro, G., Udisti, R., Zangrando, R., Gambaro, A., and Bolzacchini, E.: Sources of high $\mathrm{PM}_{2.5}$ concentrations in Milan, Northern Italy: Molecular marker data and CMB modelling, Sci. Total Environ., 414, 343-355, 2012.

Perrone, M. G., Gualtieri, M., Consonni, V., Ferrero, L., Sangiorgi, G., Longhin, E., Ballabio, D., Bolzacchini, E., and Camatini, M.: Particle size, chemical composition, seasons of the year and urban, rural or remote site origins as determinants of biological effects of particulate matter on pulmonary cells, Environ. Pollut., 176, 215-227, 2013.

Pöschl, U.: Atmospheric aerosols: Composition, transformation, climate and health effects, Angew. Chem. Int. Ed., 44, 7520 7540, 2005.

Putaud, J.-P., Van Dingenen, R., and Raes, F.: Submicron aerosol mass balance at urban and semirural sites in the Milan area (Italy), J. Geophys. Res., 107, 8198, doi:10.1029/2000JD000111, 2002.

Putaud, J.-P., Van Dingenen, R., Alastuey, A., Bauer, H., Birmili, W., Cyrys, J., Flentje, H., Fuzzi, S., Gehrig, R., Hansson, H. C., Harrison, R. M., Herrmann, H., Hitzenberger, R., Hüglin, C., Jones, A. M., Kasper-Giebl, A., Kiss, G., Kousam, A., Kuhlbusch, T. A. J., Löschau, G., Maenhaut, W., Molnar, A., Moreno, T., Pekkanen, J., Perrino, C., Pitz, M., Puxbaum, H., Querol, X., Rodriguez, S., Salma, I., Schwarz, J., Smolik, J., Schneider, J., Spindler, G., ten Brink, H., Tursic, J., Viana, M., Wiedensohler, A., and Raes, F.: A European aerosol phenomenology - 3: Physical and chemical characteristics of particulate matter from 60 rural, urban, and kerbside sites across Europe, Atmos. Environ., 44, 1308-1320, 2010.

Raes, F., Van Dingenen, R., Vignati, E., Wilson, J., Putaud, J.-P., Seinfeld, J. H., and Adams, P.: Formation and cycling of aerosols in the global troposphere, Atmos. Environ., 34, 4215-4240, 2000.

Saarikoski, S., Carbone, S., Decesari, S., Giulianelli, L., Angelini, F., Canagaratna, M., Ng, N. L., Trimborn, A., Facchini, M. C., Fuzzi, S., Hillamo, R., and Worsnop, D.: Chemical characterization of springtime submicrometer aerosol in Po Valley, Italy, Atmos. Chem. Phys., 12, 8401-8421, doi:10.5194/acp-12-84012012, 2012.

Saxena, P., Hudischewskij, A. B., Seigneur, C., and Seinfeld, J. H.: A comparative study of equilibrium approaches to the chemical characterization of secondary aerosols, Atmos. Environ., 20, 1471-1483, 1986.

Seinfeld, J. H. and Pandis, S. N.: Atmospheric chemistry and physics: From air pollution to climate change, Second Edition, Wiley-Interscience editions, 1203 pp., 2006.

Silibello, C., Calori, G., Brusasca, G., Giudici, A., Angelino, E., Fossati, G., Peroni, E., and Buganza, E.: Modelling of $\mathrm{PM}_{10}$ concentrations over Milano urban area using two aerosol modules, Environ. Modell. Softw., 23, 333-343, 2008.

Squizzato, S., Masiol, M., Brunelli, A., Pistollato, S., Tarabotti, E., Rampazzo, G., and Pavoni, B.: Factors determining the formation of secondary inorganic aerosol: a case study in the Po Valley (Italy), Atmos. Chem. Phys., 13, 1927-1939, doi:10.5194/acp13-1927-2013, 2013. 
Stockwell, W. R., Kirchner, F., Kuln, M., and Seefeld, S.: A new mechanism for regional atmospheric chemistry modelling, J. Geophys. Res., 102, 847-879, doi:10.1029/97JD00849, 1997.

Stull, R. B.: An introduction to boundary layer meteorology. Atmospheric Sciences Library, Kluwer Academinc Publishers, 666 p., 1988.

Tai, A. P. K., Mickley, L. J., and Jacob, D. J.: Correlations between fine particulate matter $\left(\mathrm{PM}_{2.5}\right)$ and meteorological variables in the United States: Implications for the sensitivity of $\mathrm{PM}_{2.5}$ to climate change, Atmos. Environ., 44, 3976-3984, 2010.

Tuccella, P., Curci, G., Visconti, G., Bessagnet, B., Menut, L., and Park, R. J.: Modelling of gas and aerosol with WRF/Chem over Europe: evaluation and sensitivity study, J. Geophys. Res., 117, D03303, doi:10.1029/2011JD016302, 2012.

Tuccella, P., Curci, G., Grell, G. A., Visconti, G., Crumeroylle, S., Schwarzenboeck, A., and Mensah, A. A.: A new chemistry option in WRF/Chem v. 3.4 for the simulation of direct and indirect aerosol effects using VBS: evaluation against IMPACTEUCAARI data, Geosci. Model Dev. Discuss., 8, 791-853, doi:10.5194/gmdd-8-791-2015, 2015.

Turpin, B. J. and Lim, H.-J.: Species contributions to $\mathrm{PM}_{2.5}$ mass concentrations: Revisiting common assumptions for estimating organic mass, Aerosol Sci. Tech., 35, 60200610, 2001.

van Donkelaar, A., Martin, R. V., Brauer, M., Kahn, R., Levy, R., Verduzco, C., and Villeneuve, P. J.: Global estimates of ambient fine particulate matter concentrations from satellite-based Aerosol Optical Depth: Development and application, Environ. Health Persp., 118, 847-855, 2010.

van Stratum, B. J. H., Vilà-Guerau de Arellano, J., Ouwersloot, H. G., van den Dries, K., van Laar, T. W., Martinez, M., Lelieveld, J., Diesch, J.-M., Drewnick, F., Fischer, H., Hosaynali Beygi, Z., Harder, H., Regelin, E., Sinha, V., Adame, J. A., Sörgel, M., Sander, R., Bozem, H., Song, W., Williams, J., and Yassaa, N.: Case study of the diurnal variability of chemically active species with respect to boundary layer dynamics during DOMINO, Atmos. Chem. Phys., 12, 5329-5341, doi:10.5194/acp-12-53292012, 2012.

Walcek, C. J. and Taylor, G. R.: A Theoretical Method for Computing VerticalDistributions of Acidity and Sulfate Production within Cumulus Clouds, J. Atmos. Sci., 43, 339-355, 1986.

Wesely, M. L.: Parameterization of surface resistance to gaseous dry deposition in regional-scale numerical models, Atmos. Environ., 23, 1293-1304, doi:10.1016/0004-6981(89)90153-4, 1989.

Whiteman, C. D.: Observations of thermally developed wind systems in mountainous terrain, Chapter 2, in: Atmospheric Processes Over Complex Terrain, edited by: Blumen, W., Meteor. Mon., 23, 5-42, 1990.
Wild, O., X. Zhu, and Prather, M. J.: Fast-J: Accurate simulation of in- and below cloud photolysis in tropospheric chemical models, J. Atmos. Chem., 37, 245-282, doi:10.1023/A:1006415919030, 2000.

Wonaschuetz, A., Sorooshian, A., Ervens, B., Chuang, P. Y., Feingold, G., Murphy, S. M., de Gouw, J., Warneke, C., and Jonsson, H. H.: Aerosol and gas re-distribution by shallow cumulus clouds: An investigation using airborne measurements, J. Geophys. Res., 117, D17202, doi:10.1029/2012JD018089, 2012.

Wong, D. N., Barth, M. Skamarock, W., Grell, G., and Worden. J.: A Budget of the Summertime Ozone Anomaly Above Southern United States using WRF-Chem, AGU Fall Meeting, San Francisco, CA, USA, 14-18 December 2009.

Yu, H., Kaufman, Y. J., Chin, M., Feingold, G., Remer, L. A., Anderson, T. L., Balkanski, Y., Bellouin, N., Boucher, O., Christopher, S., DeCola, P., Kahn, R., Koch, D., Loeb, N., Reddy, M. S., Schulz, M., Takemura, T., and Zhou, M.: A review of measurement-based assessments of the aerosol direct radiative effect and forcing, Atmos. Chem. Phys., 6, 613-666, doi:10.5194/acp-6-613-2006, 2006.

Zhang, J., and Rao, S. T.: The role of vertical mixing in the temporal evolution of ground-level ozone concentrations, J. Appl. Meteorol., 38, 1674-1691, doi:10.1175/15200450(1999)038<1674:TROVMI>2.0.CO;2, 1999.

Zhang, Q., Jimenez, J. L., Canagaratna, M. R., Allan, J. D., Coe, H., Ulbrich, I., Alfarra, M. R., Takami, A., Middlebrook, A M., Sun, Y. L., Dzepina, K, Dunlea, E., Docherty, K., DeCarlo, P. F., Salcedo, D., Onasch, T., Jayne, J. T., Miyoshi, T., Shimono, A., Hatakeyama, S., Takegawa, N., Kondo, Y., Schneider, J., Drewnick, F., Borrmann, S., Weimer, S., Demerjian, K., Williams, P., Bower, K., Bahreini, K., Cottrell, L., Griffin, R. J., Rautiainen, J., Sun, J. Y., Zhang, Y. M., and Worsnop, D. R.: Ubiquity and dominance of oxygenated species in organic aerosols in anthropogenically-influenced Northern Hemisphere midlatitudes, Geophys. Res. Lett., 34, L13801, doi:10.1029/2007GL029979, 2007.

Zhang, Y., Wen, X.-Y., Wang, K., Vijayaraghavan, K., and Jacobson, M. Z.: Probing into regional $\mathrm{O}_{3}$ and particulate matter pollution in the United States: 2. An examination of formation mechanisms through a process analysis technique and sensitivity study, J. Geophys. Res., 114, D22305, doi:10.1029/2009JD011900, 2009.

Zhang, Y., Liu, P., Liu, X.-H., Jacobson, M. Z., McMurry, P. H., Yu, F., Yu, S., and Schere, K. L.: A comparative study of nucleation parameterizations: 2. Three-dimensional model application and evaluation, J. Geophys. Res., 115, D20213, doi:10.1029/2010JD014151, 2010. 